\title{
群馬縣地方に於的万地方性甲狀腺腫の問題 第二報
}

\author{
群馬大学医学部第一內枓学敉窒（主任 七佟小次郎㸚授） \\ 小谷愛子
}

七條教授は群馬縣地方に於て眼症彇を件わぬ 甲狀腺腫を有す方著以女性を屡々見かけ，又医

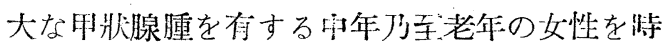
に見聞する事よりこのものが地理的に海岸線よ り比較的遠く隔つた群騭縣一带に地〉性に存在 するものではないかと推资されるに琹つた。併 し之が單なる散発性のものでなく地方性のもの であると汢定する爲にはこの地方に於ける甲狀 腺腫大度につき具体的な数を知り之と対脰地に 於けるものとの比較によりこの地に実際に甲爿 腺腫が多発している事を証明する必要がある。 この調查に際しては一定地区の全住此に就いて 行う事が望ましいが我々の呚室では便宜上主之 して小中学校生徒を対邹とし, 現在迄に群馬縣 下数ヶ所に於て甲狀腺腫大度の調查を行い更に 刘照としてて秗奈川縣藤沢市, ${ }^{122}$ ) 千葉縣船橋市, 茨 战縣水戶市, 靜岡縣菡南村, 長野縣協和村等に於 ても同樣の調查を行いその結果を数次に亘り報 告して來た。今可は昭和26年以降に行つた群婜 縣下に於怕る調查の內，佐波郡境町，群臥郡金 帛村, 利根郡片品村, 吾妻郡沢田村, 群馬郡国 府村，甘樂郡西牧村に於ける成績を報告する。

份甲狀腺腫大度测定方法は既に報告3) したも のと同一規集によつて行つた。文中の各出現率 の間の有意差の檢定には $\mathrm{x}^{2}$ テストを用い危險 率は特に $5 \%$ と記したもの>外は1\%である。

\section{1. 佐波郡境町に於ける調查成績}

調查の特：昭和 26 年2月

調查刘象：幼稚園により小学校, 中学校, 高 等学校の兒童生徒に就き調查を行つたがその內 他の成績との比較の爲 7 才より 15 才迄の者, 男 女合計1636名の成績に就いて述べる。

調查成績: 年令別, 性別に各腫大度別頻度を示 すと别表の如くである。先ず男女合計 1636 名內 男子 815 名，女子 821 名に於忊る各腫大度别頻度， を見ると表に示寸如く甲狀腺を全く触知せぬ 0
度は23.8\%を示し軽度の腫大の認められるもの は渡 $11.9 \%$ ，IＩ度20.4\%, II度で最高36.8\%に 達し二次で正常頭位で既に甲狀腺腫大を視診し得 る程度の者江 いる。之を男女別に見ると0度男子 $25.5 \%$ ，女子 $22.0 \%$, I度男子 $14.1 \%$, 女子 $9.6 \%$, I II度男子 2 $2.2 \%$ ，女子 $18.6 \%$ ，Il度男子 $32.9 \%$ ，女子 $39.7 \%$,

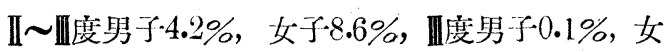
子 $1.3 \%$ という值をとつている。即ち腫大を認 めぬもの及び軽度の腫大を示すI〜II度迄は男子 は女子よりや>高い値を示し推計学的には 0 度 からI〜II度全体では男女の腫大率に有意差が認 められる。I度及びI〜相度以上は何れも女子に 高率であり男子の差は有意と認められる。之を 昭和27年度の藤沢市の小中学校に於ける調查成 績に比較すると各腫大度別の頻度では藤沢市に 於いて 0 度 $19.9 \%$ より腫大度のすっむにつれて 徐々に增加し, I度 $24.3 \%$ ，I II度 $24.7 \%$, I度 29.0 \%となり I〜吕度及び四度は夫及 $1.7 \%, 0.4 \%$ とい う低率を示しているのに対し明かに分布型の善 が認められる。又性別では腫大を認め好もの及 び腫大の軽度なものに男子が高率を上め之に刘 し明かな腫大を示すものは女子は男子より高率 である事は㒛沢市に於ても同樣に認められると ころである。

晌浆沢市の成績から狹義の思春期性甲狀腺腫 と呼び得ると思われる【〜遮及び川度の頻度は 藤沢市では男子 $1.3 \%$ ，女子 $3.0 \%$ ，男女命計 $2.1 \%$ であつたが境町では男子 815 名中 35 名 $(4.3 \%)$ 女 子 821 名中 82 名 $(10.0 \%$ ) 男子合計 1636 名中117名 (7.2\%) を示し藤沢市に比し.明かに高率である。 之を年令別に見ると7才より $1.3 \%$ の低率にはじ まり时も $0.9 \%$ と同樣低率で藤沢市と意差は 認められない。9才より12才迄も比較的低率で 9 才 $5.2 \%, 10$ 才 $5.5 \%, 11$ 才 $4.2 \%$ ， [2才 $5.0 \%$ を示 し11才及び 12 才では藤沢书と差のない程度であ 
るが境町では13才に急に增加して 19.3\%に達し 14 才 $10.2 \%$, 15 才 $18.6 \%$ と高率を示して藤沢市に 刘し著しい差を生じている。之を男女別に見る と男子は7才 $1 . .8 \%$ にばまり 9 才 $2.1 \% ， 10$ 才 4.7 \%，11才 $1.4 \% ， 12$ 才 $2.8 \%$ で年令の少いものは何 れも藤沢市との間に有意差を認められぬ程度の 低率であるが 13 才で急に $9.1 \%$ と奮加して藤沢 市より著しく高率となり14才にはや減して 3.6 \%となり有意差は認められないが15才に再び6. 0\%となり有意差を示している。女子は7才; 8才 は0.8\%，1.9\%の低率でその後や>增加するが1 2 才迄は殆ど同率て 9 才 $8.1 \% ， 10$ 才 6.4 ”，11才 6 .

$3 \% ， 12$ 才 $7.2 \%$ という值をとり 13 才に急に增扣 して $23.7 \%$ 示し14才は $16.9 \%$ ，15才で最高 30.1 \%に澾している。藤沢市では女子は7才，8才に は腫大者を見ず 9 才に $1.6 \%$ の低率にはじまり年 令と共に徐々に增加して 14 才で 最高 $4.7 \%$ に達 しているので境町は各年令共藤沢市に比し高率 であるが推計学的に見ると11才，12才ではその 差は有意とは認められず13，14，15才のもので 著明な有意差を示している。

小括：この調查地境町に䝮南東部のの平坦地 にある町でその人口の殆に゙が機㱉に從事し 1 部 烟作を行つている大体中又は中以下の生活程度 境町学童甲狀腺発育狀態調查成績（昭和26年2月）

\begin{tabular}{|c|c|c|c|c|c|c|c|c|c|c|c|c|c|c|c|c|c|}
\hline 年 & 性 & $c$ & ) & & 度 & & I & & 度 & I & $\sim$ & II & 度 & III & & & 度 \\
\hline 令 & 别 & 人賏 & $\%$ & 計 & $\%$ & 人兵 & $\%$ & 計 & $\%$ & 人員 & $\%$ & 計 & $\%$ & 人資 & $\%$ & 計 & $\%$ \\
\hline 7 & 男 & $\begin{array}{l}25 \\
22\end{array}$ & $\begin{array}{l}22.5 \\
17.7\end{array}$ & 47 & 20.0 & $\begin{array}{l}24 \\
27\end{array}$ & $\begin{array}{l}21.6 \\
21.8\end{array}$ & 51 & 21.7 & $\begin{array}{l}26 \\
30\end{array}$ & $\begin{array}{l}23.4 \\
24.2\end{array}$ & 56 & 23.8 & $\begin{array}{l}34 \\
44\end{array}$ & $\begin{array}{l}30.6 \\
35.5\end{array}$ & 78 & 33.2 \\
\hline 8 & 男 & $\begin{array}{l}34 \\
28 \\
\end{array}$ & $\begin{array}{l}30.6 \\
26.2\end{array}$ & 62 & 28.4 & $\begin{array}{l}19 \\
10\end{array}$ & $\begin{array}{r}17.1 \\
9.3\end{array}$ & 29 & 13.3 & $\begin{array}{l}22 \\
21\end{array}$ & $\begin{array}{l}19.8 \\
19.6\end{array}$ & 43 & 19.7 & $\begin{array}{l}36 \\
46\end{array}$ & $\begin{array}{l}32.4 \\
43.0\end{array}$ & 82 & 37.6 \\
\hline 9 & 男 & $\begin{array}{l}28 \\
24\end{array}$ & $\begin{array}{l}29.5 \\
24.2\end{array}$ & 52 & 26.8 & $\begin{array}{r}10 \\
5\end{array}$ & $\begin{array}{r}10.5 \\
5.1\end{array}$ & 15 & 7.7 & $\begin{array}{l}21 \\
16\end{array}$ & $\begin{array}{l}22.1 \\
16.2\end{array}$ & 37 & 19.1 & $\begin{array}{l}34 \\
46\end{array}$ & $\begin{array}{l}35.8 \\
46.5\end{array}$ & 80 & 41.2 \\
\hline 10 & 罗 & $\begin{array}{l}20 \\
26 \\
\end{array}$ & $\begin{array}{l}18.7 \\
27.7\end{array}$ & 46 & 22.9 & $\begin{array}{l}8 \\
3\end{array}$ & $\begin{array}{l}7.5 \\
3.2\end{array}$ & 11 & 5.5 & $\begin{array}{l}27 \\
18\end{array}$ & $\begin{array}{l}25.2 \\
19.1\end{array}$ & 45 & 22.4 & $\begin{array}{l}47 \\
41\end{array}$ & $\begin{array}{l}43.9 \\
43.6\end{array}$ & 88 & 43.8 \\
\hline 11 & 男 & $\begin{array}{l}24 \\
31\end{array}$ & $\begin{array}{l}34.3 \\
32.3\end{array}$ & 55 & 33.1 & $\begin{array}{r}9 \\
13\end{array}$ & $\begin{array}{l}12.9 \\
13.5\end{array}$ & 22 & 13.3 & $\begin{array}{l}14 \\
16\end{array}$ & $\begin{array}{l}20.0 \\
16.7\end{array}$ & 30 & 18.1 & $\begin{array}{l}22 \\
30\end{array}$ & $\begin{array}{l}31.4 \\
31.3\end{array}$ & 52 & 31.3 \\
\hline 12 & 女 & $\begin{array}{l}29 \\
19\end{array}$ & $\begin{array}{l}40.8 \\
27.5\end{array}$ & 48 & 34.3 & $\begin{array}{l}3 \\
3\end{array}$ & $\begin{array}{l}4.2 \\
4.3\end{array}$ & 6 & 4.3 & $\begin{array}{l}14 \\
17\end{array}$ & $\begin{array}{l}19.7 \\
24.6\end{array}$ & 31 & 22.1 & $\begin{array}{l}23 \\
25\end{array}$ & $\begin{array}{l}32.4 \\
36.2\end{array}$ & 48 & 34.3 \\
\hline 13 & 男 & $\begin{array}{r}10 \\
6\end{array}$ & $\begin{array}{r}10.0 \\
7.9\end{array}$ & 16 & 9.1 & $\begin{array}{r}10 \\
9\end{array}$ & $\begin{array}{l}10.0 \\
11.8\end{array}$ & 19 & 10.8 & $\begin{array}{l}26 \\
13\end{array}$ & $\begin{array}{l}26.0 \\
17.1\end{array}$ & 39 & 22.2 & $\begin{array}{l}38 \\
30\end{array}$ & $\begin{array}{l}38.0 \\
39.5\end{array}$ & 68 & 38.6 \\
\hline 14 & 男 & $\begin{array}{l}20 \\
16\end{array}$ & $\begin{array}{l}24.1 \\
19.3\end{array}$ & 36 & 21.7 & $\begin{array}{r}21 \\
7\end{array}$ & $\begin{array}{r}25.3 \\
8.4\end{array}$ & 28 & 16.9 & $\begin{array}{l}21 \\
13\end{array}$ & $\begin{array}{l}25.3 \\
15.7\end{array}$ & 34 & 20.5 & $\begin{array}{l}18 \\
33 .\end{array}$ & $\begin{array}{l}21.7 \\
39.8\end{array}$ & 51 & 30.7 \\
\hline 15 & 男 & $\begin{array}{r}18 \\
9\end{array}$ & $\begin{array}{l}26.9 \\
12.3\end{array}$ & 27 & 19.3 & $\begin{array}{r}11 \\
2\end{array}$ & $\begin{array}{r}16.4 \\
2.7\end{array}$ & 13 & 9.3 & $\begin{array}{r}10 \\
9\end{array}$ & $\begin{array}{l}14.9 \\
12.3\end{array}$ & 19 & 13.6 & $\begin{array}{l}24 \\
31\end{array}$ & $\begin{array}{l}35.8 \\
42.5\end{array}$ & 55 & 39.3 \\
\hline 計 & 男 & $\begin{array}{l}208 \\
181\end{array}$ & $\begin{array}{l}25.5 \\
22.0\end{array}$ & 89 & 23.8 & $\begin{array}{r}115 \\
79\end{array}$ & $\begin{array}{r}14.1 \\
9.6\end{array}$ & 194 & 11.9 & $\begin{array}{l}181 \\
153\end{array}$ & $\begin{array}{l}22.2 \\
18.6\end{array}$ & 334 & 20.4 & $\begin{array}{l}276 \\
326\end{array}$ & $\begin{array}{l}33.9 \\
39.7\end{array}$ & 602 & 36.8 \\
\hline
\end{tabular}

\begin{tabular}{|c|c|c|c|c|c|c|c|c|c|c|c|c|c|c|c|}
\hline 年 & 性 & 1 & $\sim$ & III & 度 & I & & & 度 & & & & $\sim$ III & $E+1$ & \\
\hline 令 & & 人員 & $\%$ & 計 & $\%$ & 人員 & $\%$ & 計 & $\%$ & 人員 & 計 & 人員 & $\%$ & 計 & $\%$ \\
\hline 7 & 男 & $\begin{array}{l}2 \\
1\end{array}$ & $\begin{array}{l}1.8 \\
0.8\end{array}$ & 3 & 1.3 & $\begin{array}{l}0 \\
0\end{array}$ & & 0 & & $\begin{array}{l}111 \\
124\end{array}$ & 235 & $\begin{array}{l}2 \\
1\end{array}$ & $\begin{array}{l}1.8 \\
0.8\end{array}$ & 3 & 1.3 \\
\hline 8 & 男 & $\begin{array}{l}0 \\
2\end{array}$ & 1.9 & 2 & 0.9 & $\begin{array}{l}0 \\
0\end{array}$ & & 0 & & $\begin{array}{l}111 \\
107\end{array}$ & 218 & $\begin{array}{l}0 \\
2\end{array}$ & $\begin{array}{r}0 \\
1.9\end{array}$ & 2 & 0.9 \\
\hline 9 & 男 & $\begin{array}{l}2 \\
8\end{array}$ & $\begin{array}{l}2.1 \\
8.1\end{array}$ & 10 & 5.2 & $\begin{array}{l}0 \\
0\end{array}$ & & 0 & & $\begin{array}{l}95 \\
99\end{array}$ & 194 & $\begin{array}{l}2 \\
8 \\
\end{array}$ & $\begin{array}{l}2.1 \\
8.1 \\
\end{array}$ & 10 & 5.2 \\
\hline 10 & $\begin{array}{l}\text { 獣 } \\
\end{array}$ & $\begin{array}{l}5 \\
6\end{array}$ & $\begin{array}{l}4.7 \\
6.4\end{array}$ & 11 & 5.5 & $\begin{array}{l}0 \\
0\end{array}$ & & 0 & & $\begin{array}{r}107 \\
94\end{array}$ & 201 & $\begin{array}{l}5 \\
6\end{array}$ & $\begin{array}{l}4.7 \\
6.4\end{array}$ & 11 & 5.5 \\
\hline 11 & 勇 & $\frac{1}{6}$ & $\begin{array}{l}1.4 \\
6.3\end{array}$ & 7 & 4.2 & $\begin{array}{l}0 \\
0\end{array}$ & & 0 & & $\begin{array}{l}70 \\
96\end{array}$ & 166 & $\begin{array}{l}1 \\
6\end{array}$ & $\begin{array}{l}1.4 \\
6.3\end{array}$ & 7 & 4.2 \\
\hline 12 & 男 & $\begin{array}{l}2 \\
3 \\
\end{array}$ & $\begin{array}{l}2.8 \\
4.3\end{array}$ & 5 & 3.6 & $\begin{array}{l}0 \\
2\end{array}$ & $\begin{array}{r}0 \\
2.9\end{array}$ & 2 & 1.4 & $\begin{array}{l}71 \\
69\end{array}$ & 140 & $\begin{array}{l}2 \\
5\end{array}$ & $\begin{array}{l}2.8 \\
7.2\end{array}$ & 7 & 5.0 \\
\hline 13 & $\begin{array}{l}\text { 坴 } \\
\text { 女 }\end{array}$ & $\begin{array}{l}15 \\
14\end{array}$ & $\begin{array}{l}15.0 \\
18.4\end{array}$ & 29 & 16.5 & $\begin{array}{l}1 \\
4\end{array}$ & $\begin{array}{l}1.0 \\
5.3\end{array}$ & 5 & 2.8 & $\begin{array}{r}100 \\
76\end{array}$ & 176 & $\begin{array}{l}16 \\
18\end{array}$ & $\begin{array}{r}9.1 \\
23.7\end{array}$ & 34 & 19.3 \\
\hline 14 & 男 & $\begin{array}{r}3 \\
11\end{array}$ & $\begin{array}{r}3.6 \\
13.3\end{array}$ & 14 & 8.4 & $\begin{array}{l}0 \\
3\end{array}$ & $\begin{array}{r}0 \\
3.6\end{array}$ & 3 & 1.8 & $\begin{array}{l}83 \\
83\end{array}$ & 166 & $\begin{array}{r}3 \\
14\end{array}$ & $\begin{array}{r}3.6 \\
16.9\end{array}$ & 17 & 10.2 \\
\hline 15 & 男 & $\begin{array}{r}4 \\
20\end{array}$ & $\begin{array}{r}6.0 \\
27.4\end{array}$ & 24 & 17.1 & $\begin{array}{l}0 \\
2\end{array}$ & $\begin{array}{r}0 \\
2.7\end{array}$ & 2 & 1.4 & $\begin{array}{l}67 \\
73\end{array}$ & 140 & $\begin{array}{r}4 \\
22\end{array}$ & $\begin{array}{r}6.0 \\
30.1\end{array}$ & 26 & 18.6 \\
\hline 計 & 男 & $\begin{array}{l}34 \\
71\end{array}$ & $\begin{array}{l}4.2 \\
8.6\end{array}$ & 05 & 6.4 & 11 & $\begin{array}{l}0.1 \\
1.3\end{array}$ & 12 & 0.7 & $\begin{array}{l}815 \\
821\end{array}$ & 1636 & $\begin{array}{l}35 \\
82\end{array}$ & $\begin{array}{r}4.3 \\
10.0\end{array}$ & 117 & 7.2 \\
\hline
\end{tabular}


の人口稠密な町であり現在迄の山村地帶を主と した調查地とはその生活環境も異つていると思 われる。この町の小中学校の調查成績も現在迄 の縣下各調湘とほぼ似た值を示し昭和 24 年度の 沢田村の成績を除いては皆同一母集団のものと 認められ刘照地に刘して全体として明かに高い 腫大率を示し甲狀腺腫大の地方差を証明し得る。 更に藤沢市と境町との間の II 吕度及び而度命計 の腫大率の差がて才，8才の者には認められずそ れ以上の年令殊に13才より15才の間に著しく現 れ义同じこの年令群に於て男子゙よりも女子に腫 大が著明であるという事は生理的にも甲狀腺腫 大を來す思春期に殊に女子に何等かの地方性因 子の影響により正常よりも高い明狀脉腫大率を 示すに至つたものと思われる。

\section{II：北群馬部金島村に於ける 調查成績}

調查の特：昭和 26 年 6 月

調枮刘象：北群㷂郡金島村小中学校生徒 7 求 より15才迄の男子 597 名, 女子 570 名, 男女合計 1 167 名。

調查成績：年令别，性别に於ける各腫大度别 頻度は別表に示す如くである。先ず男女合計に 就いて各腫大度别頻度を見ると甲狀腺を全く触 知せぬ 0 度は $19.7 \%$ を示し次で 度は $19.8 \%$ と同 率であるが以後腫大度のすっむにつれて次第に
篁加しI〜I度 $23.1 \%$ ，I度 $28.3 \%$ と最高に達する。 正常頭位で既に甲狀腺腫大を認め得るものは II

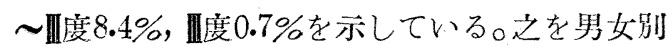
に見ると男子は0度 $20.1 \%$ ，度 $20.8 \%$ ，IＩI度 25 . $8 \%$ ，I度 $26.3 \%$ と腫大度と共に徐々に增加して

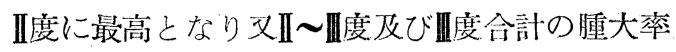
は7.0\%を示しているっ女子では0度よりI II度迄 は大体同率で 0 度 $19.3 \%$, [度18.8\%, I II度 $20.4 \%$ と认う值を示すが度の腫大者は著しく增加し て30.4\%に達しII 四度 及び 䩲命計の腫大率も 11.2\%に達している。之を昭和27年度の藤沢市 の成績に比較すると金島村では腫大の軽度なも の>率が低く之に反し腫大の明かなものが高率 で全体として分乍型の差が認められる。何各腫 大度に於ける男女の腫大率の差は腫大の軽度な ものでは男子に高率を示し之に刘し腫大の高度 なものは女子が男子より高率を示している。之 は藤沢市に於ても同樣に認められる事である。

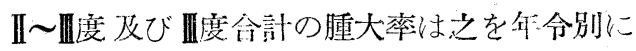
兄ると7才は男子に低率に認为られ之は藤沢术 のものと有意差が認められず 8 オには隀大者を 見ず 9 才 $6.2 \% ， 10$ 才 $5.1 \%$ とほぼ同率で两るが1 1才には $12.5 \%$ と增加の倾向を示し次で 12 才 10.5 $\% ， 13$ 才 $14.8 \% ， 14$ 才 $14.8 \% ， 15$ 才 $16.8 \%$ と徐及 に睤加して15才で最高に達し藤沢市より何れも

金島村学童甲狀腺発育狀態調查成績 (昭和26年6月)

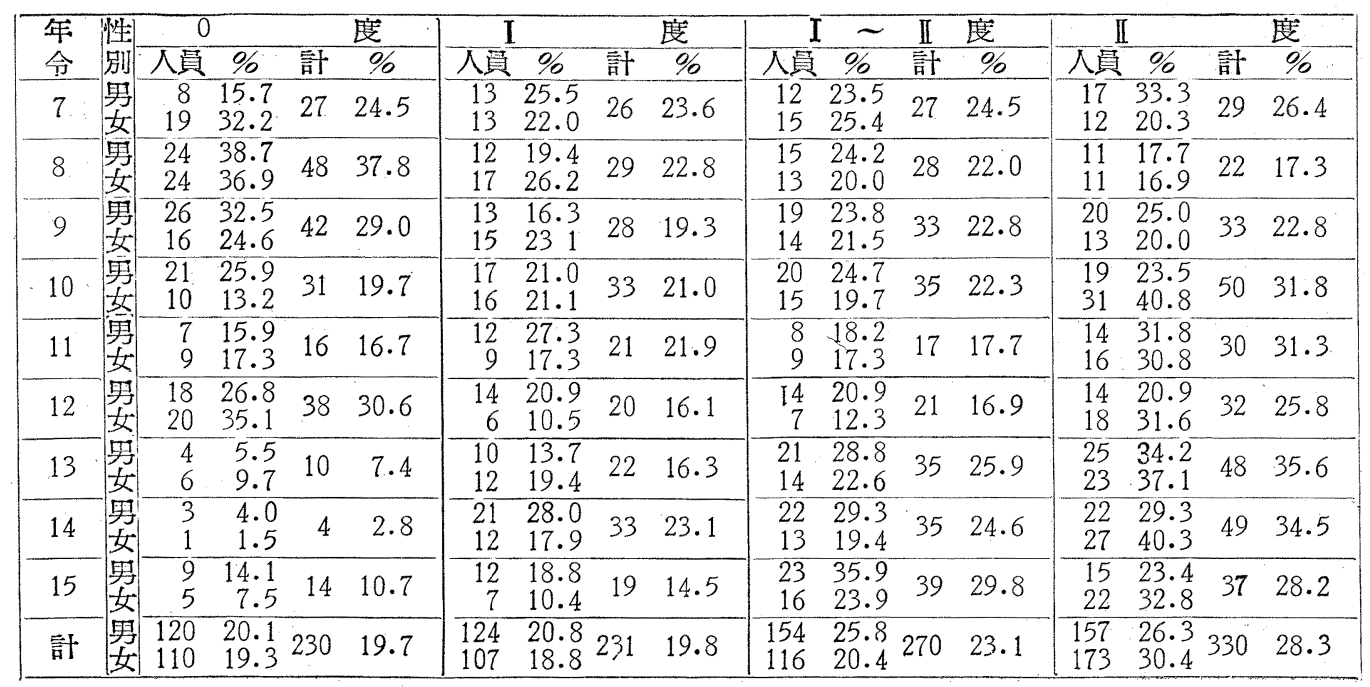




\begin{tabular}{|c|c|c|c|c|c|c|c|c|c|c|c|c|c|c|c|}
\hline 年 & 性 & I & $I \sim$ & III & 度 & III & & & 度 & & & & $\sim \mathbb{I I I}$ & 家+ II & 度 \\
\hline 命 & 別 & 人員 & $\%$ & 棓 & $\%$ & 人貝 & $\%$ & 計 & $\%$ & 人貝 & 計 & 人員 & $\%$ & 訫 & $\%$ \\
\hline 7 & 男 & 1 & 2.0 & 1 & 0.9 & $\begin{array}{l}0 \\
0\end{array}$ & & 0 & & $\begin{array}{r}51 \\
59\end{array}$ & 110 & $\begin{array}{l}1 \\
0\end{array}$ & 2.0 & 1 & 0.9 \\
\hline 8 & 男 & $\begin{array}{l}0 \\
0\end{array}$ & & 0 & & $\begin{array}{l}0 \\
0\end{array}$ & & 0 & & $\begin{array}{l}62 \\
65\end{array}$ & 127 & $\begin{array}{l}0 \\
0\end{array}$ & & 0 & \\
\hline 9 & 男 & $\begin{array}{l}2 \\
7\end{array}$ & $\begin{array}{r}2.5 \\
10.8\end{array}$ & 9 & 6.2 & $\begin{array}{l}0 \\
0\end{array}$ & & 0 & & $\begin{array}{l}80 \\
65\end{array}$ & 145 & $\begin{array}{l}2 \\
7\end{array}$ & $\begin{array}{r}2.5 \\
10.8\end{array}$ & 9 & 6.2 \\
\hline 10 & 男 & $\begin{array}{l}4 \\
4\end{array}$ & $\begin{array}{l}4.9 \\
5.3\end{array}$ & 8 & 5.1 & $\begin{array}{l}0 \\
0\end{array}$ & & 0 & & $\begin{array}{l}81 \\
76\end{array}$ & 157 & $\begin{array}{l}4 \\
4\end{array}$ & $\begin{array}{l}4.9 \\
5.3\end{array}$ & 8 & 5.1 \\
\hline 11 & 男 & $\begin{array}{l}3 \\
9\end{array}$ & $\begin{array}{r}6.8 \\
17.3 \\
\end{array}$ & 12 & 12.5 & $\begin{array}{l}0 \\
0\end{array}$ & & 0 & & $\begin{array}{l}44 \\
52\end{array}$ & 96 & $\begin{array}{l}3 \\
9\end{array}$ & $\begin{array}{r}6.8 \\
17.3\end{array}$ & 12 & 12.5 \\
\hline 12 & $\begin{array}{l}\text { 男 } \\
\text { 女 }\end{array}$ & $\begin{array}{l}7 \\
6\end{array}$ & $\begin{array}{l}10.4 \\
10.5\end{array}$ & 13 & 10.5 & $\begin{array}{l}0 \\
0\end{array}$ & & 0 & & $\begin{array}{l}67 \\
57\end{array}$ & 124 & $\begin{array}{l}7 \\
6\end{array}$ & $\begin{array}{l}10.4 \\
10.5\end{array}$ & 13 & 10.5 \\
\hline 13 & $\begin{array}{l}\text { 男 } \\
\text { 女 }\end{array}$ & $\begin{array}{r}11 \\
7\end{array}$ & $\begin{array}{l}15.1 \\
11.3\end{array}$ & 18 & 13.3 & $\begin{array}{l}2 \\
0\end{array}$ & 2.7 & 2 & 1.5 & $\begin{array}{l}73 \\
62\end{array}$ & 135 & $\begin{array}{r}13 \\
7\end{array}$ & $\begin{array}{l}17.8 \\
11.3\end{array}$ & 20 & 14.8 \\
\hline 14 & $\begin{array}{l}\text { 男 } \\
女\end{array}$ & $\begin{array}{r}6 \\
12\end{array}$ & $\begin{array}{r}8.0 \\
17.9\end{array}$ & 18 & 12.7 & $\begin{array}{l}1 \\
2\end{array}$ & $\begin{array}{l}1.3 \\
3.0\end{array}$ & 3 & 2.1 & $\begin{array}{l}75 \\
67\end{array}$ & 142 & $\begin{array}{r}7 \\
14\end{array}$ & $\begin{array}{r}9.3 \\
20.9\end{array}$ & 21 & 14.8 \\
\hline 15 & $\begin{array}{l}\text { 男 } \\
\text { 女 }\end{array}$ & $\begin{array}{r}4 \\
15\end{array}$ & $\begin{array}{r}6.3 \\
22.4\end{array}$ & 19 & 14.5 & $\begin{array}{l}1 \\
2\end{array}$ & $\begin{array}{l}1.6 \\
3.0\end{array}$ & 3 & 2.3 & $\begin{array}{l}64 \\
67\end{array}$ & 131 & $\begin{array}{r}5 \\
17\end{array}$ & $\begin{array}{r}7.8 \\
25.4\end{array}$ & 22 & 16.8 \\
\hline 計 & $\begin{array}{l}\text { 男 } \\
\text { 女 }\end{array}$ & $\begin{array}{l}38 \\
60 \\
\end{array}$ & $\begin{array}{r}6.4 \\
10.5 \\
\end{array}$ & 98 & 8.4 & $\begin{array}{l}4 \\
4\end{array}$ & $\begin{array}{l}0.7 \\
0.7 \\
\end{array}$ & 8. & 0.7 & $\begin{array}{l}597 \\
570 \\
\end{array}$ & 1167 & $\begin{array}{l}42 \\
64\end{array}$ & $\begin{array}{r}7.0 \\
11.2 \\
\end{array}$ & 106 & 9.1 \\
\hline
\end{tabular}

高率で 12 才を除いた外は有意差が認められる。

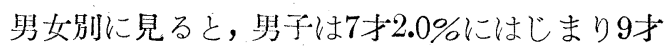
$2.5 \%$ ，10才 $4.9 \% ， 11$ 才 $6.8 \% ， 12$ 才 $10.4 \% ， 13$ 才 1 $7.8 \%$ と年令と其に增加して 13 才で最高に澾し 次で 14 才 $9.3 \%$, 15才 $7.8 \%$ とや〉減少の傾向を示 している。藤沢市の同年令群と比較して何れも 高率を示すがその差は7才及び10才，11才，12才 では有意とは認められない程度であり，年令の 多いもので著明な差を示す裀になつている。女 子に於いては7才度び8才には腫大者を見ず 9 才 $10.8 \%, 10$ 才 $5.3 \%$, 11 才 $17.3 \%, 12$ 才 $10.5 \%$, 13 才 $11.3 \% ， 14$ 才 $20.9 \% ， 15$ 才 $25.4 \%$ という值をとり 大体に於て年令の多いものに腫大者も多く 15 才 で最高を示している。藤沢の刘照群と比較する と10才及び12才ではその差は有意とは認められ ないが13才では5\%その他では1\%以下の危險率 で有意差を示している。男女の腫大率の差は13 才で男子が17.8\%で 女子の $11.3 \%$ よ高い值を 示すがこの差は推計学的には有意とは認められ ない。その他は何れも女子は男子より高率であ り殊に14才，15才で萻しい琴が認められる。

小括：調查地北群馬郡金島村け榛名山の東麓， 吾妻川に沿つたほぼ本坦な畑作を主とする農 村であるがこの地の小中学校に於ける調查成績 は現在迄に行つた縣下数ヶ所の成績々同樣対照 地藤沢市のそれに比し明かに高腫大率を示し甲
爿腺腫大度の地方差を証朋し得ると思われる。 即ち I 〜遮及びル度合計の腫大率は藤沢市の男 子 $1.3 \%$ ，女子 $3.0 \%$ ，男女合計 $2.1 \%$ に刘し金皂村 に於ては男子 $7.0 \%$ ，女子 $11.2 \%$ ，男女合計 $9.1 \%$ の高率を示し明かな有意差を示し又この腫大度 に於ては低学年の者では刘沾地之差の認められ ぬ程度の低率であり生理的にも甲壯腺腫大を來 す思高期に殊に女子に高率となり刘愍地との間 に著しい美を生ずる事が認められた。

\section{III 利根郡片品村に於ける調查成績}

調查の特：昭和27年 11 月

調查刘照：利根郡片品村小中学校生徒 男子712名, 女子 737 名, 合計 1449 名

調盐成績：各腫大度別に年令別，性別の腫大 率を示すと别表の如くなる。先ず男女命計 1449 名に就いて各腫大度別の頻度を見ると，0度より II度迄腫大度のす >むにつれて增加し 0 度 $11.0 \%$ I度 $13.4 \%$, I II度 $26.0 \%$ ，II度 $41.3 \%$ を示し，正常 頭位で既に甲壯腺腫大を視竞し得る程度のもの はI～正度 $6.2 \% ， \mathbb{1 1}$ 度 $2.0 \%$ を示している。之は同 年の藤沢市に於ける調查成績”に於て0度19.9\% I度 $24.3 \%$ ，IＩI度 $24.7 \% ，$ II度 $29.0 \%$ を徐々に增

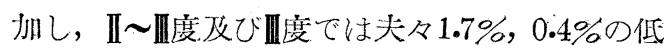
率を示しているものに比較して全体をして分布 型の差が認められる。之を性別に見ると0度では 
片品柇学童甲狀腺発育狀態調查成績 (昭和27年11月)

\begin{tabular}{|c|c|c|c|c|c|c|c|c|c|c|c|c|c|c|c|c|c|}
\hline 年 & 性 & - & D & & 度 & & & & 度 & $\therefore$ & $\sim$ & 4 & 度 & $I_{1}$ & 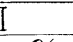 & & 度 \\
\hline 令 & 別 & 人員 & $\%$ & 計 & $\%$ & 人員 & $\%$ & 訫 & $\%$ & 人員 & $\%$ & 計 & $\%$ & 人員 & $\%$ & 計 & $\%$ \\
\hline 7 & 男 & $\begin{array}{r}7 \\
10\end{array}$ & $\begin{array}{l}10.9 \\
14.9\end{array}$ & 17 & 13.0 & $\begin{array}{l}9 \\
9\end{array}$ & $\begin{array}{l}141 \\
134\end{array}$ & 18 & 13.7 & $\begin{array}{l}24 \\
22\end{array}$ & $\begin{array}{l}37.5 \\
32.8\end{array}$ & 46 & 35.1 & $\begin{array}{l}23 \\
25\end{array}$ & $\begin{array}{l}35.9 \\
37.4\end{array}$ & 48 & 36.6 \\
\hline 8 & 罗 & $\begin{array}{r}8 \\
10 \\
\end{array}$ & $\begin{array}{l}11.8 \\
14.3\end{array}$ & 18 & 13.0 & $\begin{array}{r}13 \\
9\end{array}$ & $\begin{array}{l}19.1 \\
12.9\end{array}$ & 22 & 15.9 & $\begin{array}{l}17 \\
27 \\
\end{array}$ & $\begin{array}{r}25.0 \\
38.6 \\
\end{array}$ & 44 & 31.9 & $\begin{array}{l}29 \\
24\end{array}$ & $\begin{array}{l}42.6 \\
34.3 \\
\end{array}$ & 53 & 38.4 \\
\hline 9 & 男 & $\begin{array}{l}10 \\
13\end{array}$ & $\begin{array}{l}11.8 \\
13.7\end{array}$ & 23 & 12.8 & $\begin{array}{l}12 \\
21\end{array}$ & $\begin{array}{l}14.1 \\
22.1\end{array}$ & 33 & 18.3 & $\begin{array}{l}22 \\
23\end{array}$ & $\begin{array}{l}25.9 \\
24.2\end{array}$ & 45 & 25.0 & $\begin{array}{l}39 \\
35\end{array}$ & $\begin{array}{l}45.9 \\
36.8\end{array}$ & 74 & 41.1 \\
\hline 10 & $\begin{array}{l}\text { 男 } \\
\text { 女 }\end{array}$ & $\begin{array}{r}19 \\
4\end{array}$ & $\begin{array}{r}25.3 \\
4.9\end{array}$ & 23 & 14.7 & $\begin{array}{l}10 \\
13\end{array}$ & $\begin{array}{l}13.3 \\
16.0\end{array}$ & 23 & 14.7 & $\begin{array}{l}24 \\
22\end{array}$ & $\begin{array}{l}32.0 \\
27.2\end{array}$ & 46 & 29.5 & $\begin{array}{l}21 \\
36\end{array}$ & $\begin{array}{l}28.0 \\
44.4\end{array}$ & 57 & 36.5 \\
\hline 11 & 畕 & $\begin{array}{l}7 \\
6\end{array}$ & $\begin{array}{l}8.9 \\
6.7\end{array}$ & 13 & 7.7 & $\begin{array}{l}11 \\
15\end{array}$ & $\begin{array}{l}13.9 \\
16.9\end{array}$ & 26 & 15.5 & $\begin{array}{l}29 \\
17\end{array}$ & $\begin{array}{l}36.7 \\
19.1\end{array}$ & 46 & 27.4 & $\begin{array}{l}29 \\
44\end{array}$ & $\begin{array}{l}36.7 \\
49.4\end{array}$ & 73 & 43.5 \\
\hline 12 & $\begin{array}{l}\text { 男 } \\
\text { 女 }\end{array}$ & $\begin{array}{l}3 \\
2\end{array}$ & $\begin{array}{l}3.2 \\
1.9\end{array}$ & 5 & 2.5 & $\begin{array}{r}14 \\
9\end{array}$ & $\begin{array}{r}14.9 \\
8.5\end{array}$ & 23 & 11.5 & $\begin{array}{l}24 \\
24\end{array}$ & $\begin{array}{l}25.5 \\
22.6\end{array}$ & 48 & 24.0 & $\begin{array}{l}47 \\
53\end{array}$ & $\begin{array}{l}50.0 \\
50.0\end{array}$ & 100 & 50.0 \\
\hline 13 & 男 & $\begin{array}{l}1 \\
1\end{array}$ & $\begin{array}{l}1.3 \\
1.4\end{array}$ & 2 & 1.3 & $\begin{array}{l}6 \\
5\end{array}$ & $\begin{array}{l}7.8 \\
6.8\end{array}$ & 11 & 7.3 & $\begin{array}{l}28 \\
15\end{array}$ & $\begin{array}{l}36.4 \\
20.3\end{array}$ & 43 & 28.5 & $\begin{array}{l}36 \\
37\end{array}$ & $\begin{array}{l}46.8 \\
50.0\end{array}$ & 73 & 48.3 \\
\hline 14 & $\begin{array}{l}\text { 男 } \\
\text { 女 }\end{array}$ & $\begin{array}{r}20 \\
3\end{array}$ & $\begin{array}{r}23.5 \\
4.1 \\
\end{array}$ & 23 & 14.6 & $\begin{array}{r}14 \\
8 \\
\end{array}$ & $\begin{array}{l}16.4 \\
11.0\end{array}$ & 22 & 13.9 & $\begin{array}{l}15 \\
12\end{array}$ & $\begin{array}{l}17.6 \\
16.4\end{array}$ & 27 & 17.1 & $\begin{array}{l}33 \\
37\end{array}$ & $\begin{array}{l}38.8 \\
50.7\end{array}$ & $70^{\circ}$ & 44.3 \\
\hline 15 & 男 & $\begin{array}{l}24 \\
12 \\
\end{array}$ & $\begin{array}{l}28.2 \\
14.6\end{array}$ & 36 & 21.6 & $\begin{array}{r}12 \\
4 \\
\end{array}$ & $\begin{array}{r}14.1 \\
4.9 \\
\end{array}$ & 16 & 9.6 & $\begin{array}{l}16 \\
16 \\
\end{array}$ & $\begin{array}{l}18.8 \\
19.5\end{array}$ & 32 & 19.2 & $\begin{array}{l}24 \\
27 \\
\end{array}$ & $\begin{array}{l}28.2 \\
32.9 \\
\end{array}$ & 51 & 30.5 \\
\hline 䚵 & 界 & $\begin{array}{l}99 \\
61\end{array}$ & $\begin{array}{r}13.9 \\
8.3\end{array}$ & 160 & 11.0 & $\begin{array}{r}101 \\
93\end{array}$ & $\begin{array}{l}14.2 \\
12.6\end{array}$ & 194 & 13.4 & $\begin{array}{l}199 \\
178\end{array}$ & $\begin{array}{l}27.9 \\
24.1\end{array}$ & 377 & 26.0 & $\begin{array}{l}281 \\
318\end{array}$ & $\begin{array}{l}39.5 \\
43.1\end{array}$ & 599 & 41.3 \\
\hline
\end{tabular}

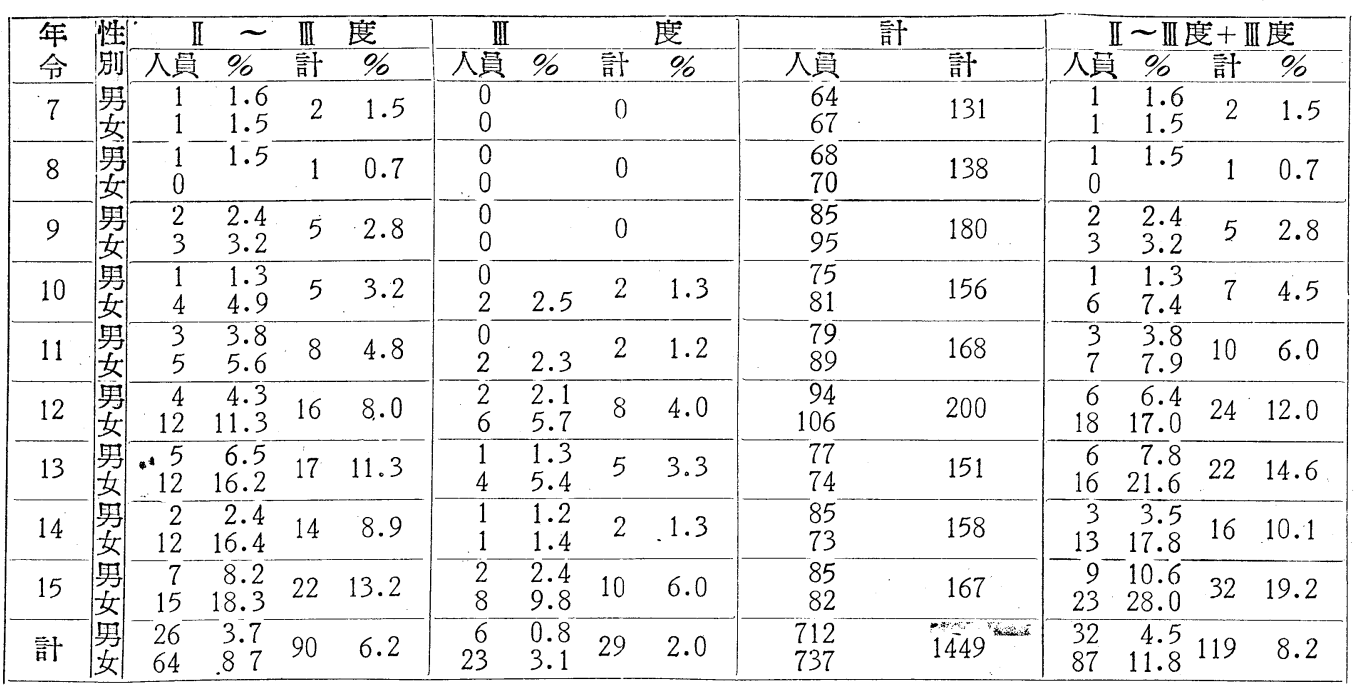

男子 $13.9 \%$ に刘し女子は $8.3 \%$ で男子に高率で女 子の腫大率との間に有意差が認められる。次で

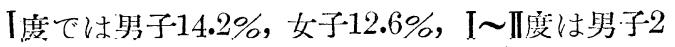
7.9\%，女子 $24.1 \%$ 男子に高い值を示すが推計 学的には有意とは認められない。とれ以上の腫 大度に於ては正度男子 $39.5 \%$,女子 $43.1 \%$, II 杖度 男子 $3.7 \%$ ，女子 $8.7 \%$ ，四度男子 $0.8 \%$ ，女子 $3.1 \%$ と何れも女子に高率を示し殊に I 〜央度及び亚度 では男子の腫大率との間に有意差が認められる この腫大を認めぬもの及び腫大の軽度なもので 男子が高率を占め腫大の著明なものは女子が男
子より高い腫大率を示す事は刘照地藤沢市にも 同㥞に認められる事である。 II 遮及び四度合 計の腫大率は藤沢市に於ては男子 $1.3 \%$, 女子 3.0 \%, 男女合計 $2.1 \%$ に過ぎなかつたが之に刘し片 品村では男子 $4.5 \%$ ，女子 $11.8 \%$ ，男女合計 $8.2 \%$ の高率を示し明かに有意美が認められる。この II 目度及び 而度合計の年令別頻度は男女合計で

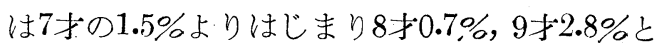
低率で藤沢甫の同年令群との間に美を認めない 程度であるが 10 才 $4.5 \%$ ，11才 $6.0 \%$ とや >增师の 傾问を示し 12 才には $12.0 \%$ と著しく增加しその 
後も 13 才 $14.6 \%$, 14 才 $10.1 \% ， 15$ 才 $19.2 \%$ と高率 を保ら 12 才以上は何れも藤沢市との間に有意差 か証明されている。之を男女别に見ると男子は 7 才 $1.6 \%, 8$ 才 $1.5 \% ， 9$ 才.4\%，10才 $1.3 \%$ と低率 て藤沢术と有意差は認められないがその後次第 に增加し 11 才 $3.8 \% ， 12$ 才 $6.4 \% ， 13$ 才 $7 . \% ， 14$ 才 $3.5 \% ， 15$ 才 $10.6 \%$ という值をとり 13 才文び15才 では藤沢可に対し有意善を示している。女子は 7才 $1.5 \%$ よはじまり8才には腫大者はなく，そ の後年令と基に增加し 9 才 $3.2 \%, 10 才 7.4 \%, 11$ 才 $7.9 \%$ ，12才 $17.0 \% ， 13$ 才 $21.6 \% ， 14$ 才 $17.8 \%$ ，15才 $28.0 \%$ 示し藤沢市の 9 才以上と比較して 9 才及 び11才の外は何れも高率で有意差が認められる 又各年令に於ける男女の腫大率の差は低学年で は認められず年令と共に女子に高率となり 12 才 13才では1〜 5\%, 14才及び15才では1\%以下の危 險率で有意差が認められる。

份この片品村は群馬縣北菓部の山岳地带を広 く占め人口密度少く恋通も不便で一般生活㻴境 にも惠まれない一山村で片品川に沿つて点在す る14の小部落より成り学校もこの地の中心地䣄 田に中学校及び小学校本校がありその他数尔所 に小学校の分校が散在している。各部落别に】〜 四度及び四度命計の腫大率を見ると最高 $14.8 \%$ よ り最低 $1.6 \%$ 迄 各部落間に相当な腫大率の美を 示し大体に於て辺鄙な地に腫大率も高く中心地 距田附近とその他の部落との間の腫大率には明 かに有意差力゙認められる。殊に鹳田に於ては最 も低率で 125 名中 2 名, $1.6 \%$ に過ざず刘奂地藤沢 市との間に有意差の認められぬ程度である。

この地の飲料水の沃度含有量は河侧によれば 5) 腫大率の低い政田附近と高率を示す辺鄙な部 落も共に他の群第縣下の調查地の殆どのものと 同㥞 $0.7 \%$ 以下であり藤沢市ょり低い値を示し ている。

小括：片品村小中学校に於ける調查成績は【I

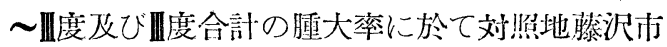
に比較して高率を示し，更にこの美は思春期に 於て殊に女子に著しく現われている。倫同村內 に於ても各部落別の腫大率には相当な差が認め
られ中心地跣田附近はその他の辺鄙な部落に比 し腫大率が低く有意差が認められる。殊に儧田 に於ては最も低率で対照地との間に有意差の認 められ程度である。沿本調查に於て辺鄙な山 間地帶の卦落に50才及び37才の女性に夫及IV度 の湤慢性甲爿腺腫を有する学を胃出した。

\section{听 吾妻郡沢田村に於ける調查成樍}

我々は昭和 2 年 11 月この小币学校に於て甲壯 腺腫大度の符一回調查を行つたがその成績は現 在迄の䅫下の調查成績中最高の腫大率を示し, 荻 沢市との差が有意であるのみならず，群婜縣下 各調查地の成績からその母:集団均一性を $\mathrm{x}^{2}$ テ ストにより檢定すると沢田村は著しく高い値を とりその他の調查と同一母集団に属するもの之 は認められないという絬果となつた。今可第一 回調丳上り三ケ年を経過してこの地に於ける高 い甲狀腺腫大率が如何なる変化を來したかを知

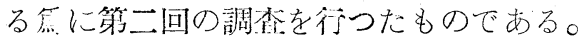

調查の特：昭和27年11月

調查刘象：吾毒郡沢田村に於ける沢渡中学校 同小学校本校父び分校諩に四厅小中学校生徒男 子744名，女子688名，男女合計1432名。

調查成績：年令別及び性别に於ける各腫大度 別の頻度は別表に示寸如くである。

今回の調香成績に於ける各䏸大度別の頻度は

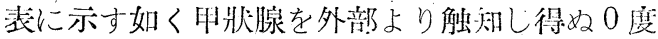
の槽は $12.0 \%$ あ゙あ次で腫大度のす〉むにつれ て次第に增加しI度 $13.1 \%$, I II度 $22.6 \%$, II度 41.3 \%を示しII 林度及び四度も夫々 $9.4 \% ， 1.5 \%$ とい う值をとつている。回の調沓成緽に於ける 0 度 $6.3 \%$, I度 $7.7 \%$, I II度 $17.1 \%$, II度 $38.9 \%$, II 正度 $23.0 \%$ ，片荠 $6.9 \%$ という值に比較して正常頭

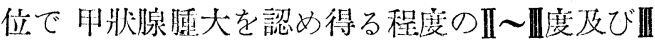

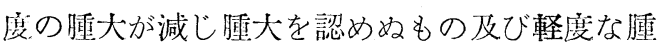
大を認めるものが增加し全体として分价型の差 が認められるこの川〜喥及び度合計の腺大率 は刘监地藤沢方2 2 では男子 $1.3 \%$ ，女子 $3.0 \%$ ，男 女合計 $2.1 \%$ という低率であるのに刘し第一回 の沢田村小中学校調查成績は男子 $22.7 \%$ ，女子 3 6.7\%，男女合計 $30.0 \%$ とい著しい高率であり 
沢田柇学童甲狀腺発青狀態調查成績（昭和27年11月）

\begin{tabular}{|c|c|c|c|c|c|c|c|c|c|c|c|c|c|c|c|c|c|}
\hline 年 & 性 & 0 & & & 度 & 1 & L & & 度 & I & $I \sim$ & II & 鹿 & I & 1 & & 度 \\
\hline 令 & 別 & 人貝 & $\%$ & 計 & $\%$ & 人員 & $\%$ & 計 & $\%$ & 人員 & $\%$ & 計 & $\%$ & 人員 & $\%$ & 計 & $\%$ \\
\hline .7 & 男 & $\begin{array}{r}11 \\
5\end{array}$ & $\begin{array}{r}18.3 \\
8.1\end{array}$ & 16 & 13.1 & $\begin{array}{r}5 \\
10 \\
\end{array}$ & $\begin{array}{r}8.3 \\
16.1\end{array}$ & 15 & 12.3 & $\begin{array}{l}19 \\
16\end{array}$ & $\begin{array}{l}31.7 \\
25.8\end{array}$ & 35 & 28.7 & $\begin{array}{l}24 \\
28\end{array}$ & $\begin{array}{l}40.0 \\
45.2\end{array}$ & 52 & 42.6 \\
\hline 8 & 罗 & $\begin{array}{l}8 \\
9\end{array}$ & $\begin{array}{l}12.1 \\
12.9\end{array}$ & 17 & 12.5 & $\begin{array}{l}14 \\
11\end{array}$ & $\begin{array}{l}21.2 \\
15.7\end{array}$ & 25 & 18.4 & $\begin{array}{l}12 \\
23\end{array}$ & $\begin{array}{l}18.2 \\
32.9\end{array}$ & 35 & 25.7 & $\begin{array}{l}31 \\
24\end{array}$ & $\begin{array}{l}47.0 \\
34.3\end{array}$ & 55 & 04 \\
\hline 9 & 界 & $\begin{array}{r}11 \\
4\end{array}$ & $\begin{array}{r}11.0 \\
5.8\end{array}$ & 15 & 8.9 & $\begin{array}{r}17 \\
8\end{array}$ & $\begin{array}{l}17.0 \\
11.6\end{array}$ & 25 & 14.8 & $\begin{array}{l}29 \\
16\end{array}$ & $\begin{array}{l}29.0 \\
23.2\end{array}$ & 45 & 26. & $\begin{array}{l}42 \\
35\end{array}$ & $\begin{array}{l}42.0 \\
50.7\end{array}$ & 77 & 45.6 \\
\hline 10 & 男 & $\begin{array}{l}14 \\
12\end{array}$ & $\begin{array}{l}14.9 \\
15.2\end{array}$ & 26 & 15.0 & $\begin{array}{l}9 \\
7\end{array}$ & $\begin{array}{l}9.6 \\
8.9\end{array}$ & 16 & 92 & $\begin{array}{l}24 \\
15\end{array}$ & $\begin{array}{l}25.5 \\
19.0\end{array}$ & 39 & 2 & $\begin{array}{l}39 \\
37\end{array}$ & $\begin{array}{l}41.5 \\
46.8\end{array}$ & 76 & 43 \\
\hline 11 & 罗 & $\begin{array}{r}11 \\
6\end{array}$ & $\begin{array}{r}12.6 \\
8.3 \\
\end{array}$ & 17 & 10.7 & $\begin{array}{r}6 \\
15\end{array}$ & $\begin{array}{r}6.9 \\
20.8\end{array}$ & 21 & 3 & $\begin{array}{l}24 \\
18\end{array}$ & $\begin{array}{l}27.6 \\
25.0\end{array}$ & 42 & 26.4 & $\begin{array}{l}38 \\
26\end{array}$ & $\begin{array}{l}43.7 \\
36.1\end{array}$ & 64 & 40.3 \\
\hline 12 & $\begin{array}{l}\text { 䔬 } \\
\text { 女) }\end{array}$ & $\begin{array}{l}22 \\
22\end{array}$ & $\begin{array}{l}21.0 \\
22.4\end{array}$ & 44 & 21.7 & $\begin{array}{r}8 \\
12\end{array}$ & $\begin{array}{r}7.6 \\
12.2\end{array}$ & 20 & 9 & $\begin{array}{l}20 \\
22\end{array}$ & $\begin{array}{l}19.0 \\
22.4\end{array}$ & 42 & 2 & $\begin{array}{l}51 \\
28\end{array}$ & $\begin{array}{l}48.6 \\
28.6\end{array}$ & 79 & 9 \\
\hline 13 & 男 & $\begin{array}{r}11 \\
4\end{array}$ & $\begin{array}{r}18.0 \\
4.9\end{array}$ & 15 & 10.5 & $\begin{array}{r}13 \\
5\end{array}$ & $\begin{array}{r}21.3 \\
6.1\end{array}$ & 18 & 12.6 & $\begin{array}{l}14 \\
15\end{array}$ & $\begin{array}{l}23.0 \\
18.3\end{array}$ & 29 & 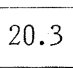 & $\begin{array}{l}19 \\
30\end{array}$ & $\begin{array}{l}31.1 \\
36.6\end{array}$ & 49 & 3 \\
\hline 14 & 罗 & $\begin{array}{l}7 \\
3\end{array}$ & $\begin{array}{l}7.8 \\
4.5\end{array}$ & 10 & 6.4 & $\begin{array}{r}14 \\
4\end{array}$ & $\begin{array}{r}15.6 \\
6.0\end{array}$ & 18 & 11.5 & $\begin{array}{l}14 \\
10\end{array}$ & $\begin{array}{l}15.6 \\
14.9\end{array}$ & 24 & 15.3 & $\begin{array}{l}44 \\
33\end{array}$ & $\begin{array}{l}48.9 \\
49.3\end{array}$ & 77 & 49.0 \\
\hline 15 & 男 & $\begin{array}{l}9 \\
3\end{array}$ & $\begin{array}{r}11.1 \\
3.4\end{array}$ & 12 & 7.1 & $\begin{array}{r}22 \\
8\end{array}$ & $\begin{array}{r}27.2 \\
9.0\end{array}$ & 30 & 17 & $\begin{array}{l}14 \\
18\end{array}$ & $\begin{array}{l}17.3 \\
20.2\end{array}$ & 32 & 18.8 & $\begin{array}{l}27 \\
36\end{array}$ & $\begin{array}{l}33.3 \\
40.4\end{array}$ & 63 & 37.1 \\
\hline 計 & $\begin{array}{l}\text { 窝 } \\
\text { 女 }\end{array}$ & $\begin{array}{r}104 \\
68 \\
\end{array}$ & $\begin{array}{r}14.0 \\
9.9 \\
\end{array}$ & 172 & 2.0 & $\begin{array}{r}108 \\
88 \\
\end{array}$ & $\begin{array}{l}14.5 \\
11.6\end{array}$ & 88 & 1301 & $\begin{array}{l}170 \\
153 \\
\end{array}$ & $\begin{array}{l}22.8 \\
22.2 \\
\end{array}$ & & 22 & $\begin{array}{l}315 \\
277\end{array}$ & $\begin{array}{l}42.3 \\
40.3 \\
\end{array}$ & 592 & 41 \\
\hline
\end{tabular}

\begin{tabular}{|c|c|c|c|c|c|c|c|c|c|c|c|c|c|c|c|}
\hline 年 & & 1 & $\sim$ & III & 度 & II & & & 度 & & & & $I \sim \mathbb{I I I}$ & 蕞+ & 度 \\
\hline 令 & 别 & 人員 & $\%$ & 計 & $\%$ & 人貫 & $\%$ & 訪 & $\%$ & 人員 & 訫 & 人員 & $\%$ & 計 & $\%$ \\
\hline 7 & 男 & $\begin{array}{l}1 \\
3\end{array}$ & $\begin{array}{l}1.7 \\
4.8\end{array}$ & 4 & 3.3 & $\begin{array}{l}0 \\
0\end{array}$ & & 0 & & $\begin{array}{l}60 \\
62\end{array}$ & 122 & $\begin{array}{l}1 \\
3\end{array}$ & $\begin{array}{l}1.7 \\
4.8\end{array}$ & 4 & 3.3 \\
\hline 8 & $\begin{array}{l}\text { 男 } \\
\text { 女 }\end{array}$ & $\begin{array}{l}1 \\
3\end{array}$ & $\begin{array}{l}1.5 \\
4.3\end{array}$ & 4 & 2.9 & $\begin{array}{l}0 \\
0\end{array}$ & & 0 & & $\begin{array}{l}66 \\
70\end{array}$ & 136 & $\begin{array}{l}1 \\
3\end{array}$ & $\begin{array}{l}1.5 \\
4.3\end{array}$ & 4 & 2.9 \\
\hline 9 & 男 & $\begin{array}{l}1 \\
4\end{array}$ & $\begin{array}{l}1.0 \\
5.8\end{array}$ & 5 & 3.0 & $\begin{array}{l}0 \\
2\end{array}$ & $\begin{array}{r}0 \\
2.9\end{array}$ & 2 & 1.2 & $\begin{array}{r}100 \\
69 \\
\end{array}$ & 169 & $\begin{array}{l}1 \\
6\end{array}$ & $\begin{array}{l}1.0 \\
8.7\end{array}$ & 7 & 4.1 \\
\hline 10 & 男 & $\begin{array}{l}7 \\
8\end{array}$ & $\begin{array}{r}7.4 \\
10.1\end{array}$ & 15 & 8.7 & $\begin{array}{l}1 \\
0\end{array}$ & $\begin{array}{r}1.1 \\
0\end{array}$ & 1 & 0.6 & $\begin{array}{l}94 \\
79\end{array}$ & 173 & $\begin{array}{l}8 \\
8\end{array}$ & $\begin{array}{r}8.5 \\
10.1\end{array}$ & 16 & 9.2 \\
\hline 11. & 女 & $\begin{array}{l}6 \\
6\end{array}$ & $\begin{array}{l}6.9 \\
8.3\end{array}$ & 12 & 7.5 & $\begin{array}{l}2 \\
1\end{array}$ & $\begin{array}{l}2.3 \\
1.4 \\
\end{array}$ & 3 & 1.9 & $\begin{array}{l}87 \\
72\end{array}$ & 159 & $\begin{array}{l}8 \\
7\end{array}$ & $\begin{array}{l}9.2 \\
9.7\end{array}$ & 15 & 9.4 \\
\hline 12 & 女 & $\begin{array}{r}4 \\
12 \\
\end{array}$ & $\begin{array}{r}3.8 \\
12.2 \\
\end{array}$ & 16 & 7.9 & $\begin{array}{l}0 \\
2 \\
\end{array}$ & $\begin{array}{r}0 \\
2.0 \\
\end{array}$ & 2 & 1.0 & $\begin{array}{r}105 \\
98 \\
\end{array}$ & 203 & $\begin{array}{r}4 \\
14 \\
\end{array}$ & $\begin{array}{r}3.8 \\
14.3 \\
\end{array}$ & 18 & 8.9 \\
\hline 13 & 军 & $\begin{array}{r}4 \\
23\end{array}$ & $\begin{array}{r}6.6 \\
28.0\end{array}$ & 27 & 18.9 & $\begin{array}{l}0 \\
5\end{array}$ & $\begin{array}{r}0 \\
6.1\end{array}$ & 5 & 3.5 & $\begin{array}{l}61 \\
82\end{array}$ & 143 & $\begin{array}{r}4 \\
28\end{array}$ & $\begin{array}{r}6.6 \\
34.1\end{array}$ & 32 & 22.4 \\
\hline 14 & 男 & $\begin{array}{l}11 \\
13\end{array}$ & $\begin{array}{l}12.2 \\
19.4\end{array}$ & 24 & 15.3 & $\begin{array}{l}0 \\
4\end{array}$ & $\begin{array}{r}0 \\
6.0\end{array}$ & 4 & 2.5 & $\begin{array}{l}90 \\
67\end{array}$ & 157 & $\begin{array}{l}11 \\
17\end{array}$ & $\begin{array}{l}12.2 \\
25.4\end{array}$ & 28 & 17.8 \\
\hline 15 & $\begin{array}{l}\text { 量 } \\
\text { 女 }\end{array}$ & $\begin{array}{r}8 \\
20\end{array}$ & $\begin{array}{r}9.9 \\
22.5\end{array}$ & 28 & 16.5 & $\begin{array}{l}1 \\
4\end{array}$ & $\begin{array}{l}1.2 \\
4.5\end{array}$ & 5 & 2.9 & $\begin{array}{l}81 \\
89\end{array}$ & 170 & $\begin{array}{r}9 \\
24\end{array}$ & $\begin{array}{l}11.1 \\
27.0\end{array}$ & 33 & 19.4 \\
\hline 計 & $\begin{array}{l}\text { 要 } \\
\text { 女 }\end{array}$ & $\begin{array}{l}43 \\
92\end{array}$ & $\begin{array}{r}5.8 \\
13.4\end{array}$ & 135 & 9.4 & $\begin{array}{r}4 \\
18\end{array}$ & $\begin{array}{l}0.5 \\
2.6\end{array}$ & 22 & 1.5 & $\begin{array}{l}744 \\
688\end{array}$ & 1432 & $\begin{array}{r}47 \\
110\end{array}$ & $\begin{array}{r}6.3 \\
16.0\end{array}$ & 157 & 11.0 \\
\hline
\end{tabular}

第二回では前回より明かに減少は認められるが 份男子 $6.3 \%$ ，女子 $16.0 \%$, 男女合計 $11.0 \%$ を示し 藤沢市に対し他の縣下各地の調查成績同樣高率 を示し甲狀腺腫大度の地方美が認められる。こ

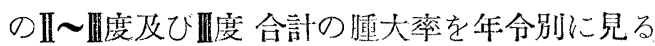
と今回の成績では男女共 7 才よりはじま 12 才 迄は著明な增加は示さず7才 $3.3 \%, 8$ 才 $2.9 \%, 9$ 才 $4.1 \%, 10$ 才 $9.2 \%$, 11 才 $9.4 \%, 12$ 才 $8.9 \%$ という值 をとつているが13才に急に $22.4 \%$ と著しく濆川 して最高となり以後 14 才 $7.8 \%$, 15才 $19.4 \%$ 略 々同樣な率を示している。第一回の調查成績で
は7才には腫大者を見ず8才に $2.6 \%$ の低率に現 れ9才 $7.7 \% ， 10 才 7.8 \%$ 示すが11才に急に增別 して $23.7 \%$ となり 12 才は略及同率の $28.7 \%$ 示 すが13才に再び著しく增加して42.7\%に達して 最高を示し炏で 14 才 $40.7 \%, 15$ 才 $42.0 \%$ と同樣の 高率を保ち今回の成績の約二倍にも達する高い 腫大率を示していた。之を男女別に見ると男子 は第一回調柋では7才，8才に腫大者はなく9才5。 $3 \%$ にはじまり年令と共に增版て13才で最高3 6.1\%に達しその後も14才 $34.8 \% ， 15$ 才 $32.4 \%$ と 同樣の高率を保つているが今回の成績では 7 才 
の $1.7 \%$ にはしまるが 8 才 $1.5 \% ， 9$ 才 $1.0 \%$ と殆ど 同率でその後や>增㞦て 10 才 $8.5 \%, 11$ 才 $9.2 \%$ 12 才 $3.8 \%, 13$ 才 $6.6 \%$ ，14才 $12.2 \% ， 15$ 才 $11.1 \%$ と

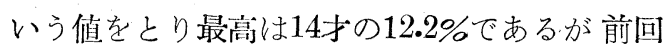
の最高值に比し約 $1 / 3$ に減少している。女子に於 ては7〜8才の $4 \%$ 台より次第に增州し 9 才 $8.7 \%$ ， 10 才 $10.1 \%$ ，11才 $9.7 \%, 12$ 才 $14.3 \%$ 示すが 13 才 に急に增加して $34.1 \%$ と最高值に達しその後も 14 才 $25.4 \%$, 15 才 $27.0 \%$ という值で思春期に一致

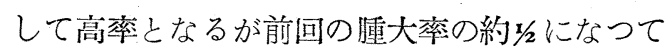
いる。併し之を藤沢市の成績に比較すると何明 かに高率を示し女子では 9 才上り15才迄各年令 で藤沢市の同年令群に比し有意差を示し男子で は7才，8才及び12才では藤沢市との差は有意と は認められぬ程度であるがその他の年令では何 れも有意差が認められ殊に年令の多いものでそ の差が著しくなつている。我及は刘照地藤沢市 の再調查を行い作次的变化を檢討した結果 0 度 より II 度迄の腫大率が二回の調查成䋶に於て相

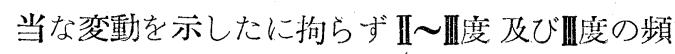
度は同程度の低率で第一回之の間に有意差は認 められなかつた。今回の沢田村に於ける成績で は三年第一回調查に於いて非常な高率を示 していた II 渡 及び四度の腫大率減じ全体とし て腫大率の低下が著しく群騭縣下各地の腫大率 より母集団均一性を檢定した場合第一问の調查 成績は明かに高率で同一母集団とは認められな かつなが今可の調榅では他の調查地と同程度の 腫大率を示す迄に減少している。この事が如何 なる原因によつて起つたかは明かでないが第一 回調查後学校保健婦が給食との他で昆师等の海 藻類の攝取を獎劭している事は興味ある事桑之 思われる。

佾この村に於けるII 四度及び III度合計の腫大 者を居住地別に見ると各字每に最高 $14.5 \%$ より 最低 $5.6 \%$ 迄かなりの差がありこの內最低值を 示す折田は他の山間の部落よりや〉ひらけた平 坦地を占めこの地方の中心地中之條町の西に隣 接しているが沢田村の平均值との間に5\%の危 險率をもつて有意差を示している。
又この村の飲料水けの沃度会有量は测村によ れば5他の縣下数ヶ所と同㥞 $0.7 \%$ 以下であり藤 沢市の值に比し低い事が証明されている。

小括：炤和 27 年 11 月，灌琴縣吾妻郡沢田村小 中学校生徒について行つた甲狀腺腫大度に関す る再調查成績では $\mathbb{I}$ 肃度 及び四度の腫大者は男 子 $6.3 \%$ ，女子 $16.0 \%$ ，男女合計 $11.0 \%$ あり，同 村に於ける昭和 24 年の第一回調查成績で 男子 2 $3.7 \%$ ，女子 $36.7 \%$ ，男女合計 $30.0 \%$ という著しい 高率を示していたものと比較すると腫大率の著 明な低下が見られるが佾他の群瑟縣下の調查成 績と同程度で刘照地藤沢市に比し明かに高率を 示している。又この村の各部落別の腫大率では この地方の中心地中之條町に僢接する部落に著 明に低率を示し沢田村平均之の間に有意美の見 られる事を知つた。

\section{V群馬郡國府村に於ける調查成績}

現在迄縣の調查地としては主として山間地方 を選んでいたが先般前橋市女子高校に於ける調 查成績に就き居任地別の頻度を檢討した結果前 橋市の西方に利根川を隔てた群騳郡国府忖の居 俧者中に甲狀腺腫大を示す者の高率に認められ る事を知り又病院外來患者中にも以前より国府 村在佳の若い女子に眠症狀を件わぬ甲狀腺腫大 が比較的多い樣に思われていたので今回この村 に於いて調查を行つたものである。

\section{調雀の特：昭和 27 年 12 月}

調查刘象：群馬郡国府村小学校及び群琵中央 的学校生徒の內国府村在住の者, 男子 358 名, 女 子349名, 男女合計707名に就いて集計を行つた。 調查成績: 甲狀腺腫大度を各年令別, 性別に 示すと表の如くである。7才より15才迄の調䄳 全員707名に於ける各腫大度別頻度は0度 $14.7 \%$ I度 $14.4 \%$, I II度 $17.4 \%$ と腫大の軽度なものは 殆ど同率であるが I度の腫大者は $41.0 \%$ と著し く增加して最高を示し更に正常頭位。柙狀腺諈

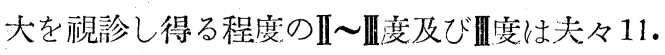
0\%, 1.4\%という值をとつている。之は対照地 藤沢术の調查成績2)に比し全体として明かに分 布型の相異が見られる，各腫大度に於ける男女 


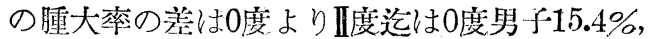
女子 $14.0 \%$ ，I度男子 $16.5 \%$ ，女子 $12.3 \%$, I III度 男子 $19.0 \%$ ，女子 $15.8 \%$, II度男子 $41.6 \%$ ，女子 40 . $4 \%$ と何れも女子より男子に高い值を示すが推 計学的にはこの差は有意とは認められない。そ れ以上の腫大度では女子は男子より高率であり II 四度男子 $7.0 \%$ ，女子 $15.2 \%$, 目度男子 $0.6 \%$ ，女 子 $2.3 \%$ 示しII 目度では有意差が認められる。 腫大度の低いものに男子が多く女子は明かな腫 大を示すものが男子より高率である事は藤沢市 にも同桃に認为られる傾向である。
この內 II 正度及び度 合計の腫大率は国府村 に於ては男子 $7.5 \%$ ，女子 $17.5 \%$ ，男女合計 $12.4 \%$ を示し独沢市に於ける男子 $1.3 \%$ ，女子 $3.0 \%$, 男 女合計 $2.1 \%$ という值に比し，明かに高率で有意 豦が認められる。之を年令別に見ると女子 7 才 男子 8 才より低率に認められ男女合計では 7 才 $1.4 \%, 8$ 才 $1.3 \% ， 9$ 才 $7.9 \% ， 10$ 才 $8.3 \% ， 11$ 才 16.5 $\% ， 12$ 才 $15.4 \% ， 13$ 才 $11.0 \% ， 14$ 才 $22.2 \% ， 15$ 才 2 $6.5 \%$ と大体年令と共に腫大率も增加している。 男女別の腫大率では男子7 才には腫大者がなく 8 才は $2.4 \% て ゙$ 滕沢市の同年令群と有意差を認め

国府村学童甲狀腺発育狀態調查成績（昭和27年12月）

\begin{tabular}{|c|c|c|c|c|c|c|c|c|c|c|c|c|c|c|c|c|c|}
\hline 年 & 性 & 0 & 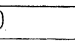 & & 度 & I & 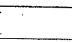 & & 度 & & $\sim$ & II & 度 & II & II & & 度 \\
\hline 令 & 別 & 人員 & $\%$ & 棓 & $\%$ & 人員 & $\%$ & 計 & $\%$ & 人員 & 計 & $\%$ & 計 & 人筫 & $\%$ & 詮 & $\%$ \\
\hline 7 & 男 & $\begin{array}{l}6 \\
8 \\
\end{array}$ & $\begin{array}{l}16.2 \\
22.9 \\
\end{array}$ & 14 & 19.4 & $\begin{array}{l}8 \\
8\end{array}$ & $\begin{array}{l}21.6 \\
22.9 \\
\end{array}$ & 16 & 22.2 & $\begin{array}{l}5 \\
5\end{array}$ & $\begin{array}{l}13.5 \\
14.3\end{array}$ & 10 & 13.9 & $\begin{array}{l}18 \\
13\end{array}$ & $\begin{array}{l}48.4 \\
37.1\end{array}$ & 31 & 43.1 \\
\hline 8 & 男 & $\begin{array}{r}13 \\
3 \\
\end{array}$ & $\begin{array}{r}31.7 \\
8.3 \\
\end{array}$ & 16 & 20.8 & $\begin{array}{l}9 \\
4\end{array}$ & $\begin{array}{l}22.0 \\
11.1\end{array}$ & 13 & 16.9 & $\begin{array}{r}9 \\
11\end{array}$ & $\begin{array}{l}22.0 \\
30.6\end{array}$ & 20 & 26.0 & $\begin{array}{r}9 \\
18 \\
\end{array}$ & $\begin{array}{l}22.0 \\
50.0 \\
\end{array}$ & 27 & 35.1 \\
\hline 9 & $\begin{array}{l}\text { 男 } \\
\text { 女 }\end{array}$ & $\begin{array}{r}8 \\
11 \\
\end{array}$ & $\begin{array}{l}20.0 \\
30.6\end{array}$ & 19 & 25.0 & $\begin{array}{l}6 \\
2\end{array}$ & $\begin{array}{r}15.0 \\
5.6\end{array}$ & 8 & 10.5 & $\begin{array}{r}10 \\
5\end{array}$ & $\begin{array}{l}25.0 \\
13.9\end{array}$ & 15 & 19.7 & $\begin{array}{l}11 \\
17\end{array}$ & $\begin{array}{l}27.5 \\
47.2\end{array}$ & 28 & 36.8 \\
\hline 10 & 男 & $\begin{array}{l}6 \\
9\end{array}$ & $\begin{array}{l}13.3 \\
23.1\end{array}$ & 15 & 17.9 & $\begin{array}{r}5 \\
10\end{array}$ & $\begin{array}{l}11.1 \\
25.6\end{array}$ & 15 & 17.9 & $\begin{array}{r}12 \\
8\end{array}$ & $\begin{array}{l}26.7 \\
20.5\end{array}$ & 20 & 23.8 & $\begin{array}{r}18 \\
9\end{array}$ & $\begin{array}{l}40.0 \\
23.1\end{array}$ & 27 & 32.1 \\
\hline 11 & 男 & $\begin{array}{l}3 \\
4\end{array}$ & $\begin{array}{r}7.7 \\
10.0 \\
\end{array}$ & 7 & 8.9 & $\begin{array}{l}6 \\
7\end{array}$ & $\begin{array}{l}15.4 \\
17.5\end{array}$ & 13 & 16.5 & $\begin{array}{l}6 \\
8\end{array}$ & $\begin{array}{l}15.4 \\
20.0\end{array}$ & 14 & 17.7 & $\begin{array}{l}21 \\
11\end{array}$ & $\begin{array}{l}53.8 \\
27.5\end{array}$ & 32 & 40.5 \\
\hline 12 & 男 & $\begin{array}{l}0 \\
0 \\
\end{array}$ & & 0 & & $\begin{array}{l}5 \\
6 \\
\end{array}$ & $\begin{array}{l}10.2 \\
14.3\end{array}$ & 11 & 12.1 & $\begin{array}{l}8 \\
5\end{array}$ & $\begin{array}{l}16.3 \\
11.9\end{array}$ & 13 & 14.3 & $\begin{array}{l}33 \\
20\end{array}$ & $\begin{array}{l}67.3 \\
47.6\end{array}$ & 53 & 58.2 \\
\hline 13 & 男 & $\begin{array}{l}5 \\
9 \\
\end{array}$ & $\begin{array}{r}13.9 \\
24.3 \\
\end{array}$ & 14 & 19.2 & $\begin{array}{l}9 \\
3 \\
\end{array}$ & $\begin{array}{r}25.0 \\
8.1 \\
\end{array}$ & 12 & 16.4 & $\begin{array}{l}6 \\
4\end{array}$ & $\begin{array}{l}16.7 \\
10.8\end{array}$ & 10 & 13.7 & $\begin{array}{l}15 \\
14 \\
\end{array}$ & $\begin{array}{l}41.7 \\
37.8\end{array}$ & 29 & 39.7 \\
\hline 14 & 男 & $\begin{array}{l}9 \\
1 \\
\end{array}$ & $\begin{array}{r}26.5 \\
2.6 \\
\end{array}$ & 10 & 13.9 & $\begin{array}{l}6 \\
1\end{array}$ & $\begin{array}{r}17.6 \\
2.6\end{array}$ & 7 & 9.7 & $\begin{array}{l}7 \\
5\end{array}$ & $\begin{array}{l}20.6 \\
13.2\end{array}$ & 12 & 16.7 & $\begin{array}{r}7 \\
20 \\
\end{array}$ & $\begin{array}{l}20.6 \\
52.6\end{array}$ & 27 & 37.5 \\
\hline 15 & 男 & $\begin{array}{l}5 \\
4 \\
\end{array}$ & $\begin{array}{r}13.5 \\
8.7 \\
\end{array}$ & 9 & 10.8 & $\begin{array}{l}5 \\
2\end{array}$ & $\begin{array}{r}13.5 \\
4.3\end{array}$ & 7 & 8.4 & $\begin{array}{l}5 \\
4\end{array}$ & $\begin{array}{r}13.5 \\
8.7\end{array}$ & 9 & 10.8 & $\begin{array}{l}17 \\
19\end{array}$ & $\begin{array}{l}45.9 \\
41.3\end{array}$ & 36 & 43.4 \\
\hline 計 & 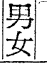 & $\begin{array}{l}55 \\
49 \\
\end{array}$ & $\begin{array}{l}15.4 \\
14.0 \\
\end{array}$ & 104 & 14.7 & $\begin{array}{l}59 \\
43 \\
\end{array}$ & $\begin{array}{l}16.5 \\
12.3 \\
\end{array}$ & 102 & 14.4 & $\begin{array}{l}68 \\
55\end{array}$ & $\begin{array}{l}19.0 \\
15.8\end{array}$ & 123 & 17.4 & $\begin{array}{l}149 \\
141\end{array}$ & $\begin{array}{l}41.6 \\
40.4\end{array}$ & 290 & 41.0 \\
\hline
\end{tabular}

\begin{tabular}{|c|c|c|c|c|c|c|c|c|c|c|c|c|c|c|c|}
\hline 年 & 性 & & $\sim$ & III & 度 & III & & & 度 & & & & $I \sim \mathbb{I I}$ & 叜 + . & I度 \\
\hline 令 & 别 & 人員 & $\%$ & 訫 & $\%$ & 人員 & $\%$ & 言 & $\%$ & 人員 & 計 & 人員 & $\%$ & 計 & $\%$ \\
\hline 7 & 男 & $\begin{array}{l}0 \\
1\end{array}$ & $\begin{array}{r}0 \\
2.9 \\
\end{array}$ & 1 & 1.4 & $\begin{array}{l}0 \\
0\end{array}$ & & C & & $\begin{array}{l}37 \\
35\end{array}$ & 72 & $\begin{array}{l}0 \\
1\end{array}$ & $\begin{array}{r}0 \\
2.9\end{array}$ & 1 & 1.4 \\
\hline 8 & 男 & $\begin{array}{l}1 \\
0\end{array}$ & $\begin{array}{r}2.4 \\
0 \\
\end{array}$ & 1 & 1.3 & $\begin{array}{l}0 \\
0\end{array}$ & & c & & $\begin{array}{l}41 \\
36\end{array}$ & 77 & $\begin{array}{l}1 \\
0\end{array}$ & $\begin{array}{r}2.4 \\
0\end{array}$ & 1 & 1.3 \\
\hline 9 & 男 & $\begin{array}{l}5 \\
1\end{array}$ & $\begin{array}{r}12.5 \\
2.8\end{array}$ & 6 & 7.9 & $\begin{array}{l}0 \\
0\end{array}$ & & c & & $\begin{array}{l}40 \\
36\end{array}$ & 76 & $\begin{array}{l}5 \\
1\end{array}$ & $\begin{array}{r}12.5 \\
2.8\end{array}$ & 6 & 7.9 \\
\hline 10 & 男 & $\begin{array}{l}3 \\
3\end{array}$ & $\begin{array}{l}6.7 \\
7.7\end{array}$ & 6 & 7.1 & $\begin{array}{l}1 \\
0\end{array}$ & $\begin{array}{r}2.2 \\
0\end{array}$ & 1 & 1.2 & $\begin{array}{l}45 \\
39\end{array}$ & 84 & $\begin{array}{l}4 \\
3\end{array}$ & $\begin{array}{l}8.9 \\
7.7\end{array}$ & 7 & 8.3 \\
\hline 11 & 男 & $\begin{array}{l}3 \\
8\end{array}$ & $\begin{array}{r}7.7 \\
20.0 \\
\end{array}$ & 11 & 13.9 & $\begin{array}{l}0 \\
2 \\
\end{array}$ & $\begin{array}{r}0 \\
5.0 \\
\end{array}$ & 2 & 2.5 & $\begin{array}{l}39 \\
40\end{array}$ & 79 & $\begin{array}{r}3 \\
10 \\
\end{array}$ & $\begin{array}{r}7.7 \\
25.0 \\
\end{array}$ & 13 & 16.5 \\
\hline 12 & 男 & $\begin{array}{l}2 \\
8\end{array}$ & $\begin{array}{r}4.1 \\
19.0\end{array}$ & 10 & 11.0 & $\begin{array}{l}1 \\
3\end{array}$ & $\begin{array}{l}2.0 \\
7.1\end{array}$ & 4 & 4.4 & $\begin{array}{l}49 \\
42\end{array}$ & 91 & $\begin{array}{r}3 \\
11\end{array}$ & $\begin{array}{r}6.1 \\
26.2\end{array}$ & 14 & 15.4 \\
\hline 13 & $\begin{array}{l}\text { 男 } \\
\text { 女 }\end{array}$ & $\begin{array}{l}1 \\
7\end{array}$ & $\begin{array}{r}2.8 \\
18.9\end{array}$ & 8 & 11.0 & $\begin{array}{l}0 \\
0\end{array}$ & & $c$ & & $\begin{array}{l}36 \\
37\end{array}$ & 73 & $\begin{array}{l}1 \\
7\end{array}$ & $\begin{array}{r}2.8 \\
18.9\end{array}$ & 8 & 11.0 \\
\hline 14 & 男 & $\begin{array}{l}5 \\
9 \\
\end{array}$ & $\begin{array}{l}14.7 \\
23.7 \\
\end{array}$ & 14 & 19.4 & $\begin{array}{l}0 \\
2\end{array}$ & $\begin{array}{r}0 \\
5.3 \\
\end{array}$ & 2 & 2.8 & $\begin{array}{l}34 \\
38\end{array}$ & 72 & $\begin{array}{r}5 \\
11 \\
\end{array}$ & $\begin{array}{l}14.7 \\
28.9\end{array}$ & 16 & 22.2 \\
\hline 14 & 男 & $\begin{array}{r}5 \\
16\end{array}$ & $\begin{array}{l}13.5 \\
34.8\end{array}$ & 21 & 25.3 & $\begin{array}{l}0 \\
1\end{array}$ & $\begin{array}{r}0 \\
2.2\end{array}$ & 1 & 1.2 & $\begin{array}{l}37 \\
46\end{array}$ & 83 & $\begin{array}{r}5 \\
17\end{array}$ & $\begin{array}{l}13.5 \\
37.0\end{array}$ & 22 & 26.5 \\
\hline 計 & 罟 & $\begin{array}{l}25 \\
53 \\
\end{array}$ & $\begin{array}{r}7.0 \\
15.2 \\
\end{array}$ & 78 & 11.0 & $\begin{array}{l}2 \\
8 \\
\end{array}$ & $\begin{array}{l}0.6 \\
2.3\end{array}$ & 10 & 1.4 & $\begin{array}{l}358 \\
349 \\
\end{array}$ & 707 & $\begin{array}{l}27 \\
61 \\
\end{array}$ & $\begin{array}{r}7.5 \\
17.5 \\
\end{array}$ & 88 & 12.4 \\
\hline
\end{tabular}


ず次で9才 $12.5 \%, 10$ 才 $8.9 \%, 11$ 才 $7.7 \%$ は何れも 藤沢市より高率となつている。12才及び13才は 腫大率をや>減じ $6.1 \%, 2.8 \%$ で费沢市と有意差 を示さないがその後再び高率となり14才 $14.7 \%$, 15 才 $13.5 \%$ と藤沢市との間に著しい美を生して いる。女子に於ては7才 $2.9 \%$ はばまり8据に は腫大者を見ず 9 才 $2.8 \% ， 10$ 才 $7.7 \%$ 年令の少 いものでは藤沢市との間に有意美を示さぬ程度 であるがその後年令と共に腫大度を霄し 11 才 2 $5.0 \% ， 12$ 才 $26.2 \%$ ，13才 $18.9 \% ， 14$ 才 $28.9 \%$ ，15才 $37.0 \%$ とう著しい高率を示し 藤沢书との差も 年令と其に點しくなつている。男子と女子の腫 大率の差は年令の少いものでは男子にや>高い 值を示すが有意とは認められず11才以上は何れ も女子に高率となり12才及び15才に於ては $5 \%$ の危險率で有意差が認められる。你门学校は国 府村及び隣接する堤ケ岡村, 金占町と三町村合 同の群馬的央学校として堤ヶ岡村に存在してい

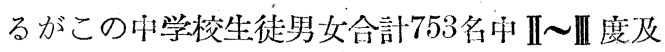
び成の腫大を示すものは 149 名19.8\%を占め町 村别では最低が堤ケ岡村の $17.3 \%$ ，次で国倠村 2 $0.0 \%$ ，最高が金古町 $23.0 \%$ となるがこの三町村 の閒の腫大率の差は有意とは認められぬ程度で あるが藤沢市の同年令群の腫大率 $2.4 \%$ に比し 何れも著しい高率となつている。

向国府村は略々平行して流れる南北二つの小 川に沿つて八部落が散在しているがこの学校調 䄳の成績に於て各部落別の腫大率を見ると畾低 $6.7 \%$ り最高 $27.5 \%$ 迄相当の美が見られ之を二 つの小川に沿つて南部の五部落上北部の三部落 に別けて兩者の間の腫大率を比較すると南の部 落群に高率で $1 \%$ 以下の危險率で有意美が認め られる。

领料水中の沃度含有量は各部落より合計 9 ケ 所の井戸水に就いて行つたがその內 6 ケ所のも のは他の縣下調查地之同樣 $0.7 \mathrm{r} /$ L以下であり 3 ケ所に(1.9r/Lを示したが何れも刘照地に比し 低い值となつている。

小括：現在迄に行つた群馬縣下の調查成續币 II 遮及び度度合計の腫大率に於て 昭和 24 年度
に行づた吾娄郡沢田村が最高の腫大率を示し制

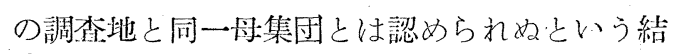
果になつているが沢田村の外，吾妻郡長野原町 嬬恋村, 利根郡水上町等縣北 北西部の山間地 方にや>高率を示す樣な印象を得ていた。併し 国府村に於て男子 $7.5 \%$ ，女子 $17.5 \%$ ，男女命計 $12.4 \%$ という腫大率を得て都方周辺の交通も比 較的便利な本坦地の些村に就てもこの程度の高 い腫大率を示すもの〉ある事を知つた。又同村 の部落別の腫大率に相当な差が見られ矧に南部 之北部の部落群の間に有意美が認められだ。

\section{VI 甘楽那西牧村に於ける調查成績}

調查の時：昭和 27 年 12 月

調查刘照: 甘樂郡西牧村小中学校生徒男子 29 6 名, 文子 285 名, 計 581 名

調查成績：男女合計 581 名に於いて各腫大度 別の頻度を年令別, 性別に示すと表の如くで 0 度のものは少数で $5.7 \%$ を示すに過ぎず腫大の 軽度なものは度 $7.9 \%$, I II度 $18.1 \%$ と增加し更 に喥は $45.6 \%$ と最高を示し 正常頭位で甲爿腺

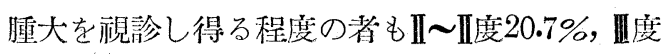
$2.1 \%$ 佮高率を示している。之は昭和 27 年度に 於ける刘照地藤沢市の調查成績に比較して腫大 度の高いものが高率を示し全体として分布型の 差が認的られる。男女別の腫大頻度は 0 度及び 渡では略々同率で0度男子 $6.1 \%$,女子 $5.3 \%$, I度 男于 $8.8 \%$ ，女子7.0\%を示すが【〜度は男子 213 $\%$ ，女子 $14.7 \%$ で男子に高率上なり正度では男子 $45.3 \%$ ，女子 $46.0 \%$ 同樣の高率となつている。 II 近度以上の腫大率は何れも女子に高く II 車度 では男子 $17.9 \%$, 女子 $23.5 \%$ ，目度で男子 $0.7 \%$, 女子 $3.5 \%$ という值を示すが师〜度では有意差 が見られぬ程度であり四度で5\%の危險率で有意 差が認められている。即ち腫大度の軽度なもの では男子が高率であり〜渡以上の著明な腫大 を示すものは女子にや>高率である。

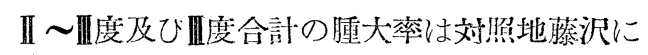

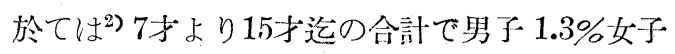
$3.0 \%$, 男女合計 $2.1 \%$ とい低率を示すに過ぎな かつたが西牧村では男子18.6\%，女子 $27.0 \%$ 男女 
西牧村学童甲狀腺発育狀態調查成績（昭和27年12月）

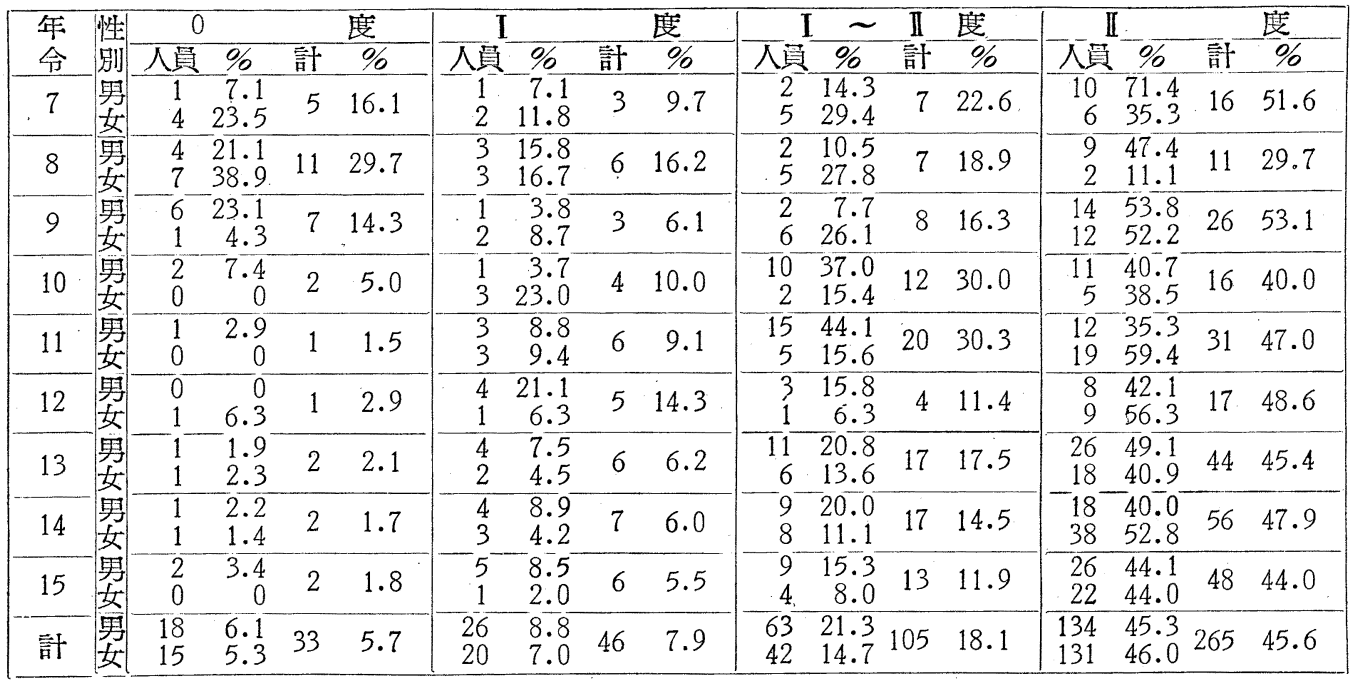

\begin{tabular}{|c|c|c|c|c|c|c|c|c|c|c|c|c|c|c|c|}
\hline 年 & 性 & II & $\sim$ & III & 度 & III & & & 度 & & & & $\mathbb{I} \sim \mathbb{I I E}$ & 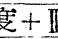 & III 度 \\
\hline 令 & 別 & 人車 & $\%$ & 計 & $\%$ & 人員 & $\%$ & 訪 & $\%$ & 人員 & 計 & 人員 & $\%$ & 計 & $\%$ \\
\hline 7 & 畕 & $\begin{array}{l}0 \\
0\end{array}$ & & 0 & & $\begin{array}{l}0 \\
0\end{array}$ & & 0 & & $\begin{array}{l}14 \\
17\end{array}$ & 31 & $\begin{array}{l}0 \\
0\end{array}$ & & 0 & \\
\hline 8 & 莮 & $\begin{array}{l}1 \\
1\end{array}$ & $\begin{array}{l}5.3 \\
5.6\end{array}$ & 2 & 5.4 & $\begin{array}{l}0 \\
0 .\end{array}$ & & 0 & & $\begin{array}{l}19 \\
18\end{array}$ & 37 & $\begin{array}{l}1 \\
1\end{array}$ & $\begin{array}{l}5.3 \\
5.6\end{array}$ & 2 & 5.4 \\
\hline 9 & 男 & $\begin{array}{l}3 \\
2\end{array}$ & $\begin{array}{r}11.5 \\
8.7\end{array}$ & 5 & 10.2 & $\begin{array}{l}0 \\
0\end{array}$ & & 0 & & $\begin{array}{l}26 \\
23\end{array}$ & 49 & $\begin{array}{l}3 \\
2 \\
\end{array}$ & $\begin{array}{r}11.5 \\
8.7\end{array}$ & 5 & 10.2 \\
\hline 10 & 勇 & $\begin{array}{l}3 \\
2 \\
\end{array}$ & $\begin{array}{l}11.1 \\
15.4\end{array}$ & 5 & 12.5 & $\begin{array}{l}0 \\
1\end{array}$ & $\begin{array}{r}0 \\
7.7\end{array}$ & 1 & 2.5 & $\begin{array}{l}27 \\
13\end{array}$ & 40 & $\begin{array}{l}3 \\
3\end{array}$ & $\begin{array}{l}11.1 \\
23.1\end{array}$ & 6 & 14.6 \\
\hline 11 & 莮 & $\begin{array}{l}3 \\
5\end{array}$ & $\begin{array}{r}8.8 \\
15.6\end{array}$ & 8 & 12.1 & $\begin{array}{l}0 \\
0\end{array}$ & & 0 & & $\begin{array}{l}34 \\
32\end{array}$ & 66 & $\begin{array}{l}3 \\
5\end{array}$ & $\begin{array}{r}8.8 \\
15.6\end{array}$ & 8 & 12.1 \\
\hline 12 & 男 & $\begin{array}{l}4 \\
2\end{array}$ & $\begin{array}{l}21.1 \\
12.5\end{array}$ & 6 & 17.1 & $\begin{array}{l}0 \\
2\end{array}$ & $\begin{array}{r}0 \\
12.5\end{array}$ & 2 & 5.7 & $\begin{array}{l}19 \\
16\end{array}$ & 35 & $\begin{array}{l}4 \\
4\end{array}$ & $\begin{array}{l}21.1 \\
25.0 \\
\end{array}$ & 8 & 22.9 \\
\hline 13 & 男 & $\begin{array}{l}11 \\
14\end{array}$ & $\begin{array}{l}20.8 \\
31.8\end{array}$ & 25 & 25.8 & $\begin{array}{l}0 \\
3 \\
\end{array}$ & $\begin{array}{r}0 \\
6.8 \\
\end{array}$ & 3 & 3.1 & $\begin{array}{l}53 \\
44\end{array}$ & 97 & $\begin{array}{l}11 \\
17\end{array}$ & $\begin{array}{l}20.8 \\
38.6\end{array}$ & 28 & 28.9 \\
\hline 14 & 男 & $\begin{array}{l}12 \\
22\end{array}$ & $\begin{array}{l}26.7 \\
30.6\end{array}$ & 34 & 29.1 & $\begin{array}{l}1 \\
0\end{array}$ & $\begin{array}{r}2.2 \\
0\end{array}$ & 1 & 0.9 & $\begin{array}{l}45 \\
72\end{array}$ & 117 & $\begin{array}{l}13 \\
22\end{array}$ & $\begin{array}{l}28.9 \\
30.6\end{array}$ & 35 & 29.9 \\
\hline 15 & 穷 & $\begin{array}{l}16 \\
19\end{array}$ & $\begin{array}{l}27.1 \\
38.0\end{array}$ & 35 & 32.1 & 4 & $\begin{array}{l}1.7 \\
8.0\end{array}$ & 5 & 4.6 & $\begin{array}{l}59 \\
50\end{array}$ & 109 & $\begin{array}{l}17 \\
23 \\
\end{array}$ & $\begin{array}{l}28.8 \\
46.0\end{array}$ & 40 & 36.7 \\
\hline 計 & 男 & $\begin{array}{l}53 \\
67\end{array}$ & $\begin{array}{l}17.9 \\
23.5\end{array}$ & & 20.7 & $\begin{array}{r}2 \\
10\end{array}$ & $\begin{array}{l}0.7 \\
3.5\end{array}$ & 12 & 2.1 & $\begin{array}{l}296 \\
285 \\
\end{array}$ & 581 & $\begin{array}{l}55 \\
77\end{array}$ & $\begin{array}{l}18.6 \\
27.0 \\
\end{array}$ & 132 & 22.7 \\
\hline
\end{tabular}

合計 $22.7 \%$ という高い值をとり著しい有意差が 認められる。この腫大度に就いて年令別の腫大 率を見ると男女合計では 7 才には腫大者を認め ず8才より5.1\%の低率にはじまり次で9才 $10.2 \%$ 10 才 $14.6 \% ， 11$ 才 $12 \cdot 1 \% ， 12$ 才 $22.9 \%$, 13 才 $28.9 \%$ 14 才 $29.9 \%$ と年令と共に腫大率も增加し 15 才に 沒高 $36.7 \%$ の高率に達している。之を藤沢市の 同年令群の腫大率とそれぞれ比較すると 8 才の 者では有意荎を認めないがそれ以上の年令では 何孔も藤沢方上り高率で明かな有意美を示し姝 に高学年に於て差が著しい。この內男子の腫大
は8才5.3\%にはじまり9才 $11.5 \% ， 10 才 11.1 \%, 11$ 才 $8.8 \%, 12$ 才 $21.1 \% ， 13$ 才 $20.8 \% ， 14$ 才 $28.9 \% ， 1$ 5 才 $28.8 \%$ という值を示し 8 才及び 12 才では藤沢 市との間に有意差を見ない程度であり 9 才及び 10才では $5 \%$ の危險率で有意差を示し13才以上 は何れも 1 以下の危險率で有意差を認め年令つ 多いもの程その美が著しくなつている。女子に 於ても 8 才 $5.6 \%$ よはじまり同樣に大体年令上 共に腫大率も增㞦し，9才8.7\%，10才 $23.1 \% ， 11$ 才 $15.6 \% ， 12$ 才 $25.0 \% ， 13$ 才 $38.6 \% ， 14$ 才 $30.6 \%$ ， 15才 $46.0 \%$ という高率を示すに至つている。9才 
以上の腫大率を藤沢甫と比較すると 9 才では藤 沢方との閒に有意差を示さない程度であるがそ れ以上の年令では何れも藤沢市に比し著しい高 率を示して明かな有意善が認められる。各年令 群に於ける男女の腫大率を比較すると 8 才及び 9 才では女子より男子に高い值を示すが有意差 は認められず10才以上になると何れも女子に高 率となるが13才に於て $5 \%$ の伦險率で有意差を 認める外はとの差は有意とは認められない程度 である。

小括：昭和27年12月に行つた甘樂郡西牧村に 於ける小中学校生徒の甲狀腺腫大率は, $\mathbb{I} \sim \mathbb{I I}$ 度 炎び目度合計で男子 $18.6 \%$ ，女子 $27.0 \%$ ，男女合計 $22.7 \%$ とう高率を示し藤沢市との間に著しい 美を示すのみならず現在迄の縣下の各調查地の 成䋶から母集団均一性を $\mathrm{x} 2$ テストにより檢定す ると之は特に高い值であり他の調查地と同一月 集団のものとは認められないという結果となう た。同樣の高率は縣北部山地間方の沢田村に於 ける昭和24年度の調查成績に見られたものであ り群騳縣下に於ても币狀腺腫大率は一律でなく 刘监地より明かに高率を示す群騭縣下一般の腫 大率より更に高い值走示す母:集団に属する地の ある事を知つた。

考按：群騳縣地方の甲爿腺腫の地方性を閆題 とするに際し我々の調夜刘㭬が主として小中学 校生徒に限られた䦭係上この年令に所謂思春期 性甲壯腺腫として生理的に現れる甲㐼腺腫大を も併せ考えねばならない。この爱刘照地として 神奈川縣荍沢市を選び昭和23年及び27年の 2 回 に亘りこの地の小中学校生徒の甲狀腺発育狀態 の調枅を行つた。その結果は既に報告した如く で，外部より既に正常頭位にて甲爿腺腫大を認 わ得る程度の II 〜II度及びIII度に相当するものが 思春期と略々一致して增加してをり 2 回の調查 成縝において甲爿腺腫大度が全体としては相当 な変化を示すが各腫大度別に見るとこの差は II 度以下の腫大率に現れ，この II 林度及び四度の 霾大率は 2 回共同率を示している事を知り又村 上氏等) の広島地方学童に於ける成績も同樣の
低率を示している事より狹義の思䒘期性印壯腺 腫とは II 〜 II度及び 四度の大さで文の蕾大率 は藤沢术に於いて男子 $1.3 \%$ ，女子 $3.0 \%$ ，男女合 計 $2.1 \%$ とり值を示す樣にあまり高率ではな いものと考えられる。今回報告した 6 万町村に 於ける II 〜 II 度及び II 度合計の腫大率は最低は 境町に於ける男子 $4.3 \%$, 女子 $10.0 \%$,男女合計 7.2 \%で次で腫大率の順に片品村男子 $4.5 \%$ ，女子 11 . $8 \%$, 男女命計 $8.2 \%$ ，金帛村男子 $7.0 \%$ ，女子 11.2 $\%$ ，男女合計 $9.1 \%$ ，沢田村男子 $6.3 \%$ ，女子 $16.0 \%$

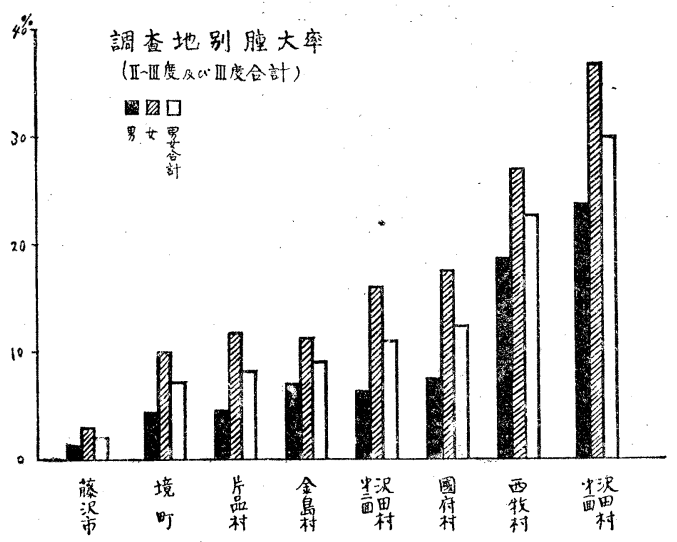

男女合計 $11.0 \%$ ，国府村男子 $7.5 \%$ ，女子 $17.5 \%$ ， 男以合計 $12.4 \%$ ，最高が西牧村の男子 $18.6 \%$ ，以 子 $27.0 \%$, 男女合計 $22.7 \%$ となり何れも藤沢术の それに比し著しい高率を示し甲狀腺腫大度の地 方美認める事が出來群馮縣地方は地方性甲狀腺 腫地帶であると云い得ると思われる。更に年令 别に見るとこの差は低学年では藤沢术の腫大率 との間に有意差を認めない程度の低率であるが 前思春期，思春期之年令の算加する行從つて殊 に女子に於て腫大率も增加し藤沢市との間に韵 しい善を示すに至つている事も生理的にも討狀 腺腫大を來すこの年令期に何等かの地方性因子 の影賠によりこの群騳縣地方一帶に刘照地の值 を超えた高率の腫大を來したものと思われる。 佁之等の甲狀腺腫は殆どすべてが游漫性で一樣 に軟かく唯低学年の者に甲狀腺全体のや〉硬い 腫大が極く稀に見られたが，パセド一氏病乃至 甲状腺機能へ進症或いは機能低下による如き臨 牀症狀を示したものは認められなかつた。 
又上述の如く群騳縣下の調䄳地に於ても各地 の胵大率の間には図に示す如く相当な美があり 之等の母集団均一性を和テストにより檢定する と西牧村及び昭和24年度の沢田村に於て他の調 业地よりも特に槀率で同一母集団とは認められ ぬ程度のものである事を知つた。又同一村冈に 於ても各部落別の腫大頻度には相当の差が認め られている。

か〉る差を來す原因を正碓に知る事は現在少 困難であるが最も広く承認されている沃度攝取 の不足という将えに基きき河村 ${ }^{5)}$ が飲料水中の沃 展含伤量を测定した結果，国府村95所，堤ケ阔 村，沢田村各2 万所多び片品村，西牧村に於ける 弞料水（井水）。の沃度含有量は国拊村の 3 万 所に0.9r/Lを示した处奶ずて $0.7 \mathrm{r} / \mathrm{L}$ 以下であ

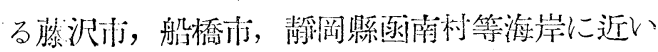
刘溜地のものより低值を示し，本縣地方一帶に 外界の沃度火之の你在する事は認められる。併 し同樣に沃度含有の少い飲料水を用いながら各 村に於て又部落聞にも明かな腫大率の美の見ら れる策や現在迄の調查印特汇高率の腫大を認め た憬下の望努郡沢田忖，甘樂郡西牧村及び長野 縣協和村等が何れも縣の法心部より隔つた山间 高原地悪を占めて居り又一つの村に於てもその 中心地より辺鄙な地に朠大率の高い傾同が見ら れる等，又瓯牧村に於ては海草類の攝取が全国 平均1日15grに刘し0という值が群馬縣衛生部の 調䄳により示されている等より飲料承山の沃度 含有量の外にも之等の辺剻な地に於ては交通の 便も㷩く食品等も㣂りやすい等，惠まれぬ一船 生活環境が何等かの影響を與えて更に高率の腫

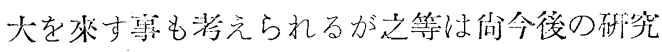
に俟たねばならない。

総括：昭和26年以降に行つた縣下小学校に

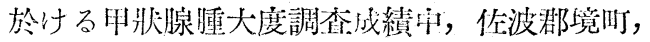

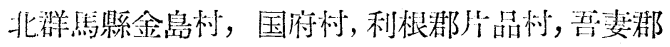
沢田村，甘樂郡西牧村に於ては先に調查を行つ た縣下各調查地と同栐刘照地藤沢市に比較して 明かに高率であり，甲狀腺偅大度の地方惹が認 められ群馬縣地方は地方性甲狀腺腫地紫である と云い得ると思われる。この內西牧村は特に著 しい高率を示し，又他の調查地間及び同一町村 內に於ても各部落に於ける腫大率の間には相当 な差が認められた。群琵縣一帶には领料水中の 沃度含有量が一般に少い事が認められるがその 他の因于の檢索は今後に残された開題である。

終りに臨み調查に当り各町村並に学校当局より賜つ た御理解之御援助を厚く御礼中上げます。或本研究の 御指導と御校閱をいたらいた七條敉授に深謝电上げ伊

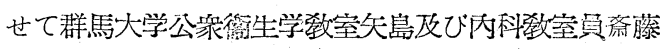
長谷川, 妹尾, 道又, 中野, 早川, 新井, 兩宮, 河村契 氏の御助力に感謝致します。

\section{交献}

1) 七條小次郎, 小谷愛子: 学童の甲狀腺発育狀態に

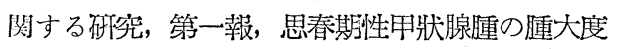
之頻度に就て 北関東医学 第1怣3-4号 1頁昭 和26年11月

2) 七條小次郎, 小谷愛子: 同上 第二報 北間東医 学 第3爸3号 49頁 昭和29年1月

3) 七條小次郎 : 群馬縣地方に於ける甲狀腺腯の問題 特にその地方病性の問題について 臨林內科小兒 科 第3卷11号 429頁 昭和23年11月

4 ）村上基千代, 高憍玉衼 : 学童の單純性甲狀腺嗹 臨林內科小兒科第5卷3号 昭和 25 年 3 月

5) 七條小次郎, 河村研介, 小谷愛子, 矢島小き : 飲 料水中のヨウ素量と單純性甲狀腺腫との関係につ いて 第26回日本內分泌学会総会演說(昭和28年) 